\title{
Corporate Environmental Performance, Environmental Management and Firm Risk
}

\begin{abstract}
Using a sample of 1,632 UK firm-year observations from 2002 to 2013, this paper investigates the impact of multi-dimensional corporate environmental performance (CEP) on firm risk. Considering two dimensions of CEP, namely environmental management performance (EMP) and environmental operational performance (EOP), we find that EMP serves as an effective mechanism in reducing firm risk and such an effect is mainly driven by the manufacturing sector. Meanwhile there is no clear association between EOP and firm risk. However, our findings highlight a moderating effect of EOP on the relationship between negative EMP and firm risk. This provides new insights into the value of multi-dimensional CEP and suggests that the complex relationship between outcome- and process-based environmental performance is important for understanding the real effects of CEP on firm risk. Our results have important implications for managerial decision-making in strategy and risk management, as well as for policy-making in environmental regulation.
\end{abstract}

Keywords: corporate environmental performance; multidimensional construct; environmental policy; carbon performance; environmental management performance; idiosyncratic risk 


\section{Introduction}

Environmental issues have been acknowledged as a major source of risk and uncertainties potentially influencing all businesses, affecting investment decisions, consumer behavior, and government policy. Since the Kyoto Protocol, an international treaty that sets emission reduction targets for industrialized countries, was introduced in 1997, national and international environmental regulations and policies have been issued and implemented. The introduction and implementation of tighter environmental regulations have predictably intensified the focus on risk, particularly regulatory risk faced by companies. The increased pressure on environmental performance measurement, reporting and transparency from tighter regulations have also increased stakeholder awareness of companies' environmental management performance. Our paper investigates the impact of companies' environmental performance on firm risk, particularly idiosyncratic risk in the stock price ${ }^{1}$. Distinct from the existing literature that examines corporate environmental performance $(\mathrm{CEP})^{2}$ as one integrated construct, we investigate the effect of different dimensions of CEP.

In the past decades, CEP has attracted considerable interest from not only policy makers, but also researchers (e.g., Horvathova, 2012; Dobler et al., 2014; Trumpp et al., 2015; Trumpp and Guenther, 2017; Shahab et al., 2018; Elmagrhi et al., 2019; Ren et al., 2019). A great number of studies have focused on examining the association between CEP and corporate financial performance (CFP). The findings of these studies generally indicate that investment in CEP is associated with superior economic performance (Busch and Hoffmann, 2011; Fujii et al., 2013; Endrikat et al., 2014; Gatimbu et al., 2018; Hang et al., 2019). By contrast, studies investigating the linkage

\footnotetext{
${ }^{1}$ As an important component of a firm's financial performance, idiosyncratic risk (also referred to as unsystematic risk) is caused by the existence of investor preference differences (Merton, 1987), and accounts for approximately " $80 \%$ of total stock risk and security price fluctuations" (Bansal and Clelland, 2004, p.94).

${ }^{2}$ Due to their repetitive re-occurrence, the abbreviations CEP (corporate environmental performance), CFP (corporate financial performance), CSR (corporate social responsibility), EMP (environmental performance management), EOP (environmental operational performance), and KPI (key performance indicator) are used throughout the paper.
} 
between firms' environmental issues and firm risk are rare; nevertheless, the limited evidence available indicates that greater commitment to environmental or social responsibility is able to help firms to: (i) reduce financial risk (Salama et al., 2011; Cai et al., 2016); (ii) diminish stakeholders' negative impressions about a firm (Godfrey, 2005; Godfrey et al., 2009); and (iii) mitigate potential bankruptcy or financial distress (Al-Hadi et al., 2019). These studies suffer from several discernible limitations.

First, the existing studies have mainly examined the effect of CEP on systematic risk from a portfolio theory perspective (e.g., Salama et al., 2011; Cai et al., 2016). While it is recognized that the implication of environmental management, such as the establishment of environmental strategy and policies as well as improvements in environmental operational performance and greenhouse gas emissions, are mainly firm-specific in nature (Lee and Faff, 2009; Harjoto and Laksmana, 2018), the effect of CEP on idiosyncratic risk is empirically unclear.

Second, previous studies have examined environmental performance and responsibility as a single or mono-dimensional construct (e.g., Fujii et al., 2013; Dobler et al., 2014; Trumpp and Guenther, 2017; Gatimbu et al., 2018; Shahab et al., 2018). Despite a consensus on the multidimensional nature of CEP, few studies on CEP have taken this into account. Based on the investigation of environmental standards and policies in different countries, recent studies on environmental performance evaluation infer a multidimensional construct of CEP as environmental management performance (EMP) and environmental operational performance (EOP) (Xie and Hayase, 2007; Busch and Hoffmann, 2011; Trumpp et al., 2015; Hartmann and Vachon, 2018; Ren et al., 2019). The EMP dimension focuses on process-based environmental performance, such as environmental policies, strategies, objectives, processes, and monitoring. The EOP captures the actual environmental outcomes and is typically measured by resources consumption and/or carbon and waste emissions. As stakeholders may interpret EMP and EOP differently, taking CEP as a mono-dimensional construct may produce ambiguous results in terms of the impact of CEP. In addition, with limited studies considering a multidimensional construct, the 
nature of the relationship between EMP and EOP as interdependent or otherwise is still arguable, with inconclusive results.

To address such limitations, this study employs a comprehensive and coherent measurement of CEP with both dimensions incorporated, but separately considered. We intend to study how different dimensions of CEP affect firms' idiosyncratic risk, using a multi-industry sample of UK companies from the FTSE ALL SHARE between 2002 and 2013. Considering total risk and idiosyncratic risk, we test (i) the impact of EMP and EOP on firm risk; (ii) the interactive effects of EMP and EOP on firm risk; and (iii) potential crossindustry variation in the above relationships.

The United Kingdom is chosen as the empirical setting for this study for several reasons. Primarily, the UK has been at the forefront of developing environmental laws and regulations since the 1950s when the Clean Air Act 1956 was introduced. As one of the Annex I Parties to the Kyoto Protocol, the UK government enacted the Climate Change Act 2008 along with a range of environmental policies ${ }^{3}$ in order to comply with the carbon emission reduction targets, and they assigned the Environment Agency to be responsible for the enforcement of such environmental laws ${ }^{4}$. UK companies were encouraged to implement environmental management systems to help improve their overall environmental performance (DEFRA, 2011; 2012). In particular, the UK government's regulations focused on compelling firms to measure and report on their level of greenhouse gas emissions and the impact of their activities on other environmental issues (DEFRA, 2013). This long regulatory tradition and related enforcement have endowed on UK companies more acute awareness of environmental issues and high involvement in environmental management. Moreover, in recent years, there has been a substantial increase in socially responsible investment in the UK especially from

\footnotetext{
3In 2011, the UK Department for Environment, Food \& Rural Affairs (DEFRA) published "Environmental key performance indicators: Reporting guidelines for UK business". It then published "Small business user guide: Guidance on how to measure and report your greenhouse gas emissions" in 2012. Later in 2013, DEFRA published the "Environmental reporting guidelines: including Streamlined Energy and Carbon Reporting requirements" in 2013, which was updated in March 2019.

${ }^{4}$ This can be found at https://www.gov.uk/government/publications/environment-agencyenforcement-and-sanctions-policy/environment-agency-enforcement-and-sanctions-policy [Accessed on 19 August 2019].
} 
institutional investors with socially responsible mandates who drive demand for improvements in social and environmental performance. As one of the world's leading global financial centers, the UK also leads the world in green finance ${ }^{5}$. Currently the UK government is devoted to developing the world's first green and sustainable finance management standards to promote green finance (DEFRA, 2018), which makes our study a timely investigation on how investors value the environmental performance of UK companies.

To the best of our knowledge, this study is the first to provide a comprehensive evaluation of the effects of a multidimensional CEP on firm risk. It attempts to contribute to the literature on CEP and its impact on firm risk by applying a multi-theoretical framework and offering detailed empirical evidence.

Firstly, we examine the impact of CEP dimensions on firms' idiosyncratic risk, addressing a significant gap in CEP literature. Prior studies on the impact of CEP mainly focus on CFP, with the exception of Cai et al. (2016) who study the relationship between environmental responsibility and firms' systematic risk. However, owing to differences in investor preference and less diversified portfolios caused by the 'neglect effect' (Hong and Kacpeczyk, 2009; Bouslah et al., 2013) as well as the fact that environmental management strategies and activities are firm-specific in nature (Harjoto and Laksmana, 2018), the impact of CEP on firms' idiosyncratic risk warrants further attention. Our results support the hypothesis that environmental management performance reduces firm-specific risk.

Secondly, our study explicitly quantifies the risk effects associated with the two CEP dimensions - namely EMP and EOP - as well as the interactions between the two dimensions, which extends our knowledge on the nature of CEP and its impact. Our findings indicate that the market ascribes different value to the two dimensions of CEP, and EOP has a moderating effect on the relationship between negative EMP and firm risk. This provides empirical evidence on how investors interpret the mixed picture of CEP when a

\footnotetext{
${ }^{5}$ As of May 2017, there were nearly 80 green bonds listed on the London Stock Exchange, having raised more than US $\$ 24 \mathrm{bn}$. See https://www.lseg.com/green [Accessed on 19 August 2019].
} 
company shows positive environmental management with high emissions or heavy pollution, or vice versa.

Finally, our study explores the possible impact of industry on the relationship between CEP and firm risk, motivated by divergent investor attitudes towards the manufacturing and service sectors given their contrasting environmental involvement. Our findings suggest that, for manufacturing companies, only EMP negatively affects a firm's risk; while for service companies, EMP and EOP both have negative impacts on a firm's risk along with a moderation effect.

Our study deepens the understanding of risk implications for corporate managers and investors concerned with the impact of environmental issues. The results indicate that investment in environmental performance provides insurance for investors and is priced in by the financial markets. Therefore, investors should account for a firm's environmental performance in their portfolio construction. We recommend senior managers include environmental management within corporate strategy and risk management, particularly for manufacturing companies. Our findings also provide information for policymakers and regulatory authorities.

The remainder of this paper is structured as follows. Section 2 provides background to UK environmental policies and rationale for considering CEP as a multi-dimensional construct. Section 3 presents theories explaining relationship between CEP and idiosyncratic risk, and Section 4 reviews the empirical literature and develops hypotheses. We present our data, variables and empirical models in Section 5, and the empirical results and discussion in Section 6. The final section concludes, providing the implications and limitations of this study.

\section{UK Environmental Policies and Multidimensional Construct of CEP}

As one of the 15 member states of the European Union (EU) with a legally binding emission reduction commitment under the Kyoto Protocol, the UK was 
assigned with a target to reduce greenhouse gas emissions by 12.5 per cent below base year levels ${ }^{6}$ on average over the period 2008-2012. To comply with the Kyoto Protocol and achieve the target, the Climate Change Act 2008 was enacted, providing the government with the power - known as the 'Adaptation Reporting Power' - to ensure that the statutory undertaker ${ }^{7}$ and bodies must address current and future climate impacts. Subsequently, several environmental policies for businesses and households were implemented in order to achieve carbon emission reduction targets. Consequently, environmentally impactful and energy-intensive industries would face direct regulatory risk from their obligation to control pollution, thereby leading to increased investment in and cost of environmental activity. Nonetheless, non-environmentally impactful industries were also to face the indirect effect of increased environmental regulations through suppliers, consumers and even energy prices.

To encourage businesses to improve their overall environmental performance, the UK government published 'Environmental Reporting Guidelines'8 to help companies address their most significant environmental impacts and manage and report on their environmental performance. The guidelines encourage companies to employ environmental management systems to manage and report environmental issues and risk. They stipulate that reports on environmental performance should include not only quantitative data, such as emissions estimations to reflect outcomes, but also the internal processes, systems and procedures, and the development of corporate environmental strategy ${ }^{9}$. This explicitly construes environmental performance as more than just specified outcomes like emission reduction.

Following the recognition of CEP as a multi-dimensional construct in regulations, recent environmental studies also suggest that one reason for the inconsistent results of the CEP-CFP relationship yielded by empirical studies

\footnotetext{
${ }^{6}$ The Kyoto Protocol uses a base year namely 1990 for carbon dioxide, methane and nitrous oxide, and 1995 for fluorinate compounds (DECC, 2015).

${ }^{7}$ Under the definition in the Climate Change Act 2008, statutory undertakers are those bodies identified in the Town and Country Planning Act.

${ }^{8}$ This can be viewed at https://www.gov.uk/government/publications/environmental-keyperformance-indicators-reporting-guidelines-for-uk-business [Accessed 19 August 2019].

${ }^{9}$ Environmental key performance indicators: Reporting guidelines for UK Business (DEFRA, 2011).
} 
could be taking CEP as a mono-dimensional construct (Walls et al., 2011; Endrikat et al., 2014). It is suggested that CEP consists of two main dimensions: (i) a process dimension named environmental management performance (EMP); and (ii) an outcome dimension named environmental operational performance (EOP) (llinitch et al., 1998; Xie and Hayase, 2007; Busch and Hoffmann, 2011; Endrikat et al., 2014; Bhattacharyya and Cummings, 2015; Trumpp et al., 2015). The EMP dimension reflects a firm's internal effort to address environmental issues and focuses on managerial strategy and processes, including environmental policies, objectives, and management structures. The EOP dimension represents the operational level of performance and focuses on outcomes, usually measured by the amount of released pollutants.

Based on the varied interests linked with companies' environmental and economic performance, different stakeholders may react variously to a firm's EMP and EOP, and the firm could also enact different responses according to their capability. Hence, it is necessary to examine the roles played by these two environmental dimensions separately. For example, llinitch et al. (1998) argue that the process dimension reflecting structural and systemic characteristics of a company is useful for its internal tracking and to some stakeholders such as employees, consumers, and shareholders; while the outcome dimension reflecting quantifiable results achieved by the company could be more attractive to bankers and investors. Following llinitch et al. (1998), more recent studies have adopted and developed multidimensional CEP frameworks (e.g., Xie and Hyase, 2007; Bhattacharyya and Cummings, 2015; Misani and Pogutz, 2015; Escrig-Olmedo et al., 2017; Ren et al., 2019), which indicates a certain degree of consensus on the process- and outcome-based multidimensional nature of CEP.

Given the multidimensional nature of CEP, one cannot transfer the results yielded by one dimension onto either the other or the overall construct. Previous studies on the relationship between CEP and CFP suggest that the results vary depending on which dimension is addressed. For example, Endrikat et al. (2014) find that EOP has positive influence on subsequent market-based CFP while EMP shows no such impact, suggesting that the 
market values a firm's environmental impact using observable and quantifiable results (Konar and Cohen, 2001) but not their environmental management activities as they can be less reliably scrutinized or even subjected to 'window-dressing' (Busch and Hoffmann, 2011).

Moreover, it is still debatable whether EMP and EOP dimensions are interdependent or independent of each other. Since a firm's environmental management system identifies its specific management environment and corporate activities, the EMP dimension indicates the capability and effort that a company invests in attempting to improve its environmental impacts (Xie and Hyase, 2007; Trumpp et al., 2015). Therefore, EMP can be considered as the precursor to EOP, while EOP indicates the quantifiable results of EMP. However, other studies find EMP and EOP to be independent of each other and offer alternative explanations. The first, proposed by Delmas et al. (2013), explains that although proactive EMP represents the potential for improvement in outcomes, there is no guarantee that the materialization of such improvement would occur imminently. The second suggests that is possible for firms to use EMP solely for the purpose of creating an environmental friendly image and moderating relationships with various stakeholders, such as customers and shareholders, rather than actually improving their environmental performance (Jung et al., 2001; Xie and Hayase, 2007; Nawrocka and Parker, 2009).

Taken together, to fully comprehend the nature of CEP and its relationship with firm risk, we incorporate the multidimensions of CEP in our study, and examine the impact of the EMP and EOP dimensions separately, as well as their interactions.

\section{Theoretical Framework for CEP and Firm Risk}

Idiosyncratic risk reflects the variability in a firm's stock price associated with firm-specific events. Although modern portfolio theory states that idiosyncratic risk does not matter in asset pricing as it can be diversified away, it does concern investors especially when considering social and environmental 
issues. Unlike traditional investors who only consider financial risk and return, socially responsible investors tend to employ both financial and non-financial criteria (such as CEP) in their investment decisions (Heinkel et al., 2001; Mackey et al., 2007). The existence of investor preference differences causes the 'neglect effect', resulting in fluctuations in idiosyncratic risk (Hong and Kacperczuk, 2009; Bouslah et al., 2013). The existence of the 'neglect effect' may push socially responsible stocks towards being in excessive demand and hence overvalued, leading to lower risk. By contrast, socially irresponsible stocks with deficit demand are undervalued, which leads to higher risk since investors tend to require additional premium as a compensation. Because of the 'neglect effect' or less diversified portfolios, idiosyncratic risk matters for pricing. Moreover, the implication of environmental management is often firmspecific in nature (Walls et al., 2011), so it provides a good domain in which to test our hypotheses on the impact of CEP on idiosyncratic risk.

Given the multi-dimensional nature of CEP and the lack of empirical evidence on the relationship between CEP and idiosyncratic risk, there is no one theoretical framework able to fully explain the impact of the multiple dimensions of CEP on firm risk. In response to recent calls for theoretical integration on this (Haque and Ntim, 2018; Shahab et al., 2018; Elmagrhi et al., 2019; Shahab et al., 2019), our study adopts a multi-theoretical perspective to develop our arguments through diverse but somewhat complementary lenses. Specifically, we draw from agency theory, stakeholder theory, the natural-resource-based view and legitimacy theory.

The agency theory lens suggests that managers (agents) are often self-motivated to maximize their own interests with shareholders' (principals') investment, and the principal-agent conflict arises due to information asymmetry and contrasting risk-sharing attitudes (Ross, 1973; Jensen and Meckling, 1976). Hence, observable and quantifiable outcome-based environmental performance reduces information asymmetry, which is likely to reduce firm risk. However, investment in environmental management can increase firm risk because managers may fail to act in the best interests of shareholders; such investment may not lead to better financial results especially in the short term (Sarkis and Cordeiro, 2001) or managers may 
over-invest for their private benefit (Barnea and Rubin, 2010). It can be argued, based on agency theory, that investment in improving EMP will place the company at a competitive disadvantage and will negatively impact firm performance with higher risk, unless there is observable improvement on EOP that could reduce the information asymmetry and thereby firm risk. However, the usefulness of agency theory in explaining the motivation of CEP is somewhat limited, due to its tendency for excessive focus on self-interest in managers at the expense of examining their competence (Van Slyke, 2006).

An alternative lens, stakeholder theory, suggests that proactive environmental management and good environmental outcomes can enhance the fulfillment of stakeholder expectation and improve corporate image and reputation among stakeholders (Jones, 1995). Superior reputation based on improved CEP could reduce conflicts of interest between managers and environmental activists (Choi and Wang, 2009; Jo and Harjoto, 2011, 2012), and result in fewer financial constraints and easier access to financial markets (Cheng et al., 2014), consequently reduce risk.

This is consistent with the natural-resource-based view (Hart, 1995), which proposes that pursuing proactive environmental strategies can generate moral capital or goodwill for companies (Trumpp and Guenther, 2017), resulting in increased competitive advantage if the environmental strategy is supported by or aligned with a firm's core competencies (Sharma and Vredenburg, 1998; Clarkson et al., 2011). Consequently, investment in CEP could increase corporate profitability and reduce firm risk.

However, considering the wide spectrum of diverse stakeholders with potentially conflicting interests, stakeholder theory and nature-resource-based view fail to provide mangers with specific guidance on how to differentiate and prioritize stakeholders' varying interests, which allows managers to pursue their own interests at the expense of firm and society (Jensen, 2001). To address such limitations, researchers extend stakeholder theory by suggesting enlightened value maximization, within which making decisions based on a firm's long-term value is in the best interests of all stakeholders (Jensen, 2001), or stakeholder synergy perspective, which promotes simultaneous rather than rotating or salience-prioritized value creation for 
essential stakeholders (Tantalo and Priem, 2016). Such development enables more subtle strategies to address conflicts among different stakeholders. It implies that investing in environmental management and improving environmental performance will increase the value of the firm and reduce financial risk since managers have incentives to pursue a goal of value maximisation. However, the market could remain ignorant of firms' environmental activities and performance in the short-run until they learn to lead the market towards understanding the full value and implications of their environmental policies.

The final lens is legitimacy theory (Suchman, 1995) for which Bansal and Clelland (2004) define corporate environmental legitimacy as the generalized perception of a firm's desirable or appropriate corporate environmental performance. Firms with higher environmental legitimacy may be associated with lower idiosyncratic risk since they often have better access to resources (Cai et al., 2016) or benefit from reduced internal and external stakeholder scrutiny, with an "insurance-like" protection (Godfrey, 2005; Godfrey et al., 2009). Moreover, manufacturing and service industry firms have differing levels of environmental legitimacy; manufacturing firms have higher regulatory pressures over environmental performance and more attention from local community and customer activism. However, legitimacy theory is impaired as it does not specify the identity of stakeholders or prioritize shareholders' expectations (Ntim and Soobaroyen, 2013; Elmagrhi et al., 2019).

Taken together, these existing theoretical frameworks offer all possible outcomes in terms of the direction of the relationship between EOP/EMP and firm risk. Agency theory suggests a negative impact of investment in EMP on firm performance with higher risk, but observable improvement on EOP may reduce information asymmetry and hence lower firm risk. Stakeholder theory, the natural-resource-based view and extended stakeholder theories suggest that investment in improving environmental performance (both EOP and EMP) will increase a firm's competitive advantage, creating better brand images or gaining stakeholder support (Hart and Ahuja, 1996; Busch and Hoffmann, 2011; Clarkson et al., 2011; Fujii et al., 2013; Trumpp and Guenther, 2017), 
and thus reducing firm risk. In addition, legitimacy theory indicates that engaging in environmental management and improving environmental performance fulfill society's expectation and benefit firms with increased shareholder wealth through insurance-like protection, improved strategic risk management, and improved transparency (Sharfman and Fernando, 2008; Godfrey et al., 2009; Goss and Roberts, 2011; Jo and Na, 2012), which will potentially reduce firm risk. As each theory has limitations in fully explaining the relationship between CEP and firm risk, in this study we adopt a multitheoretical framework to provide such an explanation with richer perspectives.

\section{Empirical Literature and Hypotheses Development}

In associating CEP and firm risk, to the best of our knowledge, no empirical literature has studied the separate impacts of EOP and EMP on firm risk. Most studies consider CEP as a single construct or just one dimension of a firm's social performance; many have centered on systematic risk. For example, using UK data between 1994 and 2006, Salama et al. (2011) report that companies' environmental performance is inversely related to systematic risk, while Cai et al. (2016), using a US sample between 1991 and 2012, report that corporate environmental responsibility inversely affects firms' systematic risk. Exceptionally, considering environment as one dimension of a firm's CSR, Bouslah et al. (2013) test its impact on firms' idiosyncratic risk and find that environment as a dimension is positively related to idiosyncratic risk for S\&P 500 firms but has no such relationship or significance for non-S\&P 500 firms.

Without any direct empirical evidence on the impact of EMP and EOP on idiosyncratic risk, and with existing evidence on the relationship between CEP and firm risk being inconsistent, plus our multi-theoretical framework suggesting that either a positive or negative association is plausible, we state the following null hypotheses:

Hypothesis 1. There is no relationship between EMP and a firm's idiosyncratic risk. 
Hypothesis 2. There is no relationship between EOP and a firm's idiosyncratic risk.

Since the EMP and EOP are conceptually distinct constructs reflecting different perspectives of companies' environmental performance, we intend to further investigate the interactive effect of EMP and EOP on a firm's idiosyncratic risk.

Environmental policies and processes are usually more difficult to measure and only indicate the intention and potential for improvement without any guarantee of outcomes (Delmas et al., 2013). According to legitimacy theory, firms adopt environmental policies and management primarily for achieving legitimacy, rather than actually expecting outcomes (Bansal and Clelland, 2004). However, the stakeholder and extended stakeholder theories suggest that the environmental processes could improve the relationship with stakeholders and benefit the firm in the long run. This leads us to propose that there is an interactive effect between EOP and EMP. Using empirical evidence, Bird et al. (2007) argue that the market requires firms to satisfy environmental regulations, and meanwhile punishes those firms who proactively invest corporate resources on environmental activities that exceed minimum requirements. Misani and Pogutz (2015) also find environmental processes moderate the relationship between a firm's carbon performance and CFP. Therefore, our third hypothesis is:

Hypothesis 3. There is an interactive effect between EMP and EOP on their relationship with a firm's idiosyncratic risk.

Further, based on legitimacy theory, there is potential cross-industry variation in the relationship between multi-dimensional CEP and firm risk. Much of the research on the CEP-CFP relationship examines the manufacturing and service sectors separately since stakeholders in distinct industries have distinct expectations, and their concerns vary widely in intensity. Cai et al. (2016) provides empirical evidence to show that in the manufacturing sector there is a negative relationship between environmental 
responsibility and firm risk, while in the service sector the relationship tends to be positive. They argue that because the environment is not seen as directly sensitive to service sector activity, their intensive investment in environmental activity may not be valued by the financial markets, which can subsequently increase firm risk. Moreover, Jo and $\mathrm{Na}$ (2012) examine the relationship between CSR and firm risk in controversial industries ${ }^{10}$ and reveal that their inverse relationship is more economically and statistically significant in such industries than in non-controversial industries. In summary, we derive the following hypothesis:

Hypothesis 4. Under the cross-industry context, for companies in manufacturing and service industries, the relationships between EMP/EOP and a firm's idiosyncratic risk are different.

\section{Research Design}

\subsection{Data and Sample}

To test the above hypotheses, we utilized data from the ASSET4 database that provides environmental, social and governance (ESG) information, and the Thomson Datastream database that provides financial information, stock prices and volatilities. In particular, the ASSET4 database provides ESG information collected through a systematic and standardized process from wide-ranging sources, including annual reports, stock exchange documents, non-governmental organization reports, and company websites, since 2002 (Ziegler et al., 2011). The ASSET4 ESG framework evaluates each company against approximately 700 individual data points that are then combined into over 250 key performance indicators (KPIs). These KPI scores are then aggregated into a framework with 18 categories grouped within four pillars namely, economic, environmental, social, and governance - and a single

\footnotetext{
${ }^{10}$ They followed the Journal of Business Ethics special issue guidelines and defined controversial industries as both those considered 'sinful' (e.g., tobacco, gambling, weapons, alcohol, adult entertainment) and those that inherently provoke persistent or emerging environmental, social, or ethical controversies (e.g., nuclear, oil, cement and biotech).
} 
overall score is allocated for each company. For the environmental pillar, a company is assigned $70 \mathrm{KPIs}$. Although the ASSET4 database was primarily designed for professional purposes, it has been commonly used in academic studies on sustainability-related topics (e.g., Stellner et al., 2015; Benlemlih et al., 2018; Haque and Ntim, 2018; Hartmann and Vachon, 2018; Moussa et al., 2019).

Our sample includes a wide cross-section of UK companies from the FTSE ALL SHARE with available data on environmental performance in the Thomson Reuters ASSET4 database. After matching the two databases and accounting for gaps and changes in variables, our final sample consists of 1,632 firm-year observations in 292 firms, covering a period of 12 years from 2002 to 2013. The ASSET4 ESG data is only available from 2002 onwards; we refrain from using ESG data beyond 2013 because all UK listed companies have been required to report their greenhouse gas emissions as part of their annual directors' report since October $2013^{11}$. In this case, we exploit the data prior to this pivotal change in regulation to ensure consistency in environmental reporting. Of these, 924 firm-year observations are from manufacturing, while 708 belong to service industries. Table 1 presents the composition of the sample companies by sector and year.

[Insert TABLE 1 around here]

\subsection{Variables}

\subsubsection{Independent Variable - CEP}

CEP is considered a multidimensional construct with two main dimensions: (i) a process dimension (EMP); and (ii) an outcome dimension (EOP) (Xie and Hayase, 2007; Busch and Hoffmann, 2011; Endrikat et al., 2014; Misani and Pogutz, 2015; Trumpp et al., 2015). In this study, we incorporate two

\footnotetext{
${ }^{11}$ Companies Act 2006 (Strategic Report and Directors' Report) Regulations 2013. Available at: http://www.legislation.gov.uk/ukdsi/2013/9780111540169/contents [Accessed on 19 July 2019].
} 
independent variables to represent the EMP and EOP dimensions, respectively.

The EOP dimension represents the outcome of environmental management activities. Since carbon performance has become a strategic issue for companies and has attracted increasing attention from stakeholders (Clemens and Bakstran, 2010), we use it as the indicator for the EOP dimension, following previous studies (e.g., Busch and Hoffmann., 2011; Fujii et al., 2013; Misani and Pogutz, 2015). Specifically, we use environmental efficiency (EE), which is defined as the desirable output per environment input, calculated as the inverse ratio of carbon emissions per net sales - the higher the sales per carbon emissions, the higher the environmental performance. In the ASSET4 database, carbon emissions are measured as "total $\mathrm{CO}_{2}$ and $\mathrm{CO}_{2}$ equivalents emissions in tonnes divided by net sales" (Thomson-Reuters, 2015).

The EMP dimension reflects the specific management processes and activities that firms have adopted to reduce environmental impact. We identified the KPIs in the ASSET4 database related to environmental management process, activities, policy and reporting, and created a new score using equal-weighted average. These scores represent the scope and intensity of a firm's EMP'12.

\subsubsection{Dependent Variable - Firm Risk}

In line with the existing literature, we measure a firm's total risk (DEVRET) using the annualized standard deviation of the firm's daily stock returns (e.g., Bouslah et al., 2013; Benlemlih et al., 2018). For idiosyncratic risk, which accounts for approximately " $80 \%$ of total stock risk and security price fluctuations" (Bansal and Clelland, 2004: p.94), we adopt three measures to proxy: the standard deviation of the residuals from CAPM using daily stock return (CAPM_IDIO); the standard deviation of residuals from the Fama and French three-factor model, based on daily stock return (FAMA_IDIO); and the

\footnotetext{
${ }^{12}$ The details of the EMP-related KPIs are listed in Appendix 1.
} 
standard deviation of residuals from the CHRHART four-factor model using daily stock return (CHRHART_IDIO).

\subsubsection{Control Variables}

Based on previous CSR and environmental performance and risk studies (e.g., Bouslah et al., 2013; Cai et al., 2016; Benlemlih et al., 2018), we control for a number of firm-specific characteristics. First, we control for firm size (SIZE), firm profitability (ROS), and leverage (LEVERAGE). Following previous studies, we further control for a firm's investment opportunities (CAPITAL); research and development intensity (R\&D); and asset growth (GROWTH). We add ASSET4's corporate governance score (CGSCORE) as a control variable to measure the company's corporate governance systems and processes, since it could influence shareholder or investor perceptions of the firm, and hence the firm's risk (Misani and Pogutz, 2015). We also add a dummy variable to represent firms that have joined the United Nations' Global Compact Program (UNGC). This program is the largest voluntary corporate responsibility initiative in the world (Rasche et al., 2013) whose participants are encouraged to adhere to environmental-, social- and governance-related principles. Participation could thus be considered a proxy for a firm's ESG performance (Soleimani et al., 2014; Misani and Pogutz, 2015). The definitions and constructions of all the variables are presented in Table 2.

\section{[Insert TABLE 2 around here]}

\subsection{Empirical Models}

Following previous literature (e.g., Misani and Pogutz, 2015; Cai, et al., 2016; Benlemlih et al., 2018), we used ordinary least squares (OLS) regression to test our hypotheses. To address potential endogeneity bias arising from reverse causality between the multidimensional environmental performance and firm risk, the lagged value of firm risk is used in the models (Misani and Pogutz, 2015; Cai et al., 2016). Industry and year fixed-effects are included in 
the regressions to control for any unobserved industry characteristics or macroeconomic shocks that could simultaneously influence CEP and firm risk (Benlemlih et al., 2018). Furthermore, we centralize the component variables of the interaction terms to reduce potential multicollinearity. Specifically, we estimate the following baseline empirical models to examine the intertemporal effect of EMP and EOP and firm risk.

$$
\begin{aligned}
\text { Firm risk }_{i, t}= & \alpha+\beta_{1} E M P_{i, t-1}+\gamma C_{i, t-1}+\text { Industry \& Year Dummies }+\varepsilon_{i, t-1} \\
\text { Firm risk }_{i, t}= & \alpha+\beta_{1} E M P_{i, t-1}+\beta_{2} E E_{i, t-1}+\gamma C_{i, t-1}+\text { Industry \& Year Dummies }+\varepsilon_{i, t-1} \\
\text { Firm risk }_{i, t}= & \alpha+\beta_{1} E M P_{i, t-1}+\beta_{2} E E_{i, t-1}+\beta_{3} E M P_{i, t-1} * E E_{i, t-1}+\gamma C_{i, t-1} \\
& + \text { Industry\& Year Dummies }+\varepsilon_{i, t-1}
\end{aligned}
$$

Here, $i$ denotes the firm and $t$ denotes the period. Firm risk represents one of the risk measures, including stock volatility or idiosyncratic risk. EE represents environmental efficiency, which measures a firm's EOP. EMP is the environmental management performance. $C$ represents a vector of all the control variables defined in Table 2.

We examine the relationship between EMP and firm risk in Eq. (1), and the impact of EMP and EE on firm risk in Eq. (2). The interactions between carbon performance and environmental management performance terms are added to explore the interaction effect of EOP and EMP on firm risk in Eq. (3).

\section{Empirical Results and Discussion}

\subsection{Descriptive Statistics and Univariate Analysis}

Table 3 provides descriptive statistics. To mitigate the effect of any extreme values, we winsorized all continuous variables at the $1 \%$ level. As shown in this table, the mean value of stock volatility for our sample is 0.021 , with a median volatility of 0.018 . In terms of the firm's non-systematic risk, the average CAMP_IDIO is 0.018 , with a median of 0.015 and standard deviation 
of 0.009 , which is in line with reported values in previous studies (e.g., Benlemlih et al., 2018). The other two measures of idiosyncratic risk used have slightly lower values: the mean (median) for FAMA_IDIO is 0.017 (0.014) and for CARHART_IDIO is $0.017(0.014)$. With respect to the two dimensions of CEP, the process-based dimension EMP has a mean (median) score of 55.068 (54.143) with a standard deviation of 11.86, and the outcomebased dimension EE has a mean of 0.707 and median of 0.175 with a standard deviation of 1.976. Both measures indicate that our sample firms have wide spectra of CEP.

Focusing on the control variables, the average ROS ratio is $18.193 \%$ and the average size measured as natural log of assets is 15.215. Capital expenditures over total assets (CAPITAL) and asset growth (GROWTH) are 0.048 and 0.088 . The average cashflow over total assets is $16.677 \%$ and the R\&D expenditure over total assets is $1.177 \%$. Of our sample firms, only $18.3 \%$ adhered to the UNGC principles. The average ASSET4 Corporate Governance Score of our sample firms is 78.713 , indicating that on average the firms have good corporate governance performance.

\section{[Insert TABLE 3 around here]}

Table 4 shows the Pearson correlation matrix for all the variables to test for multicollinearity. Interestingly, the bivariate correlations among firm risk measures, explanatory, and control variables are fairly low, indicating an absence of any multi-collinearity issues. The only notably higher correlation exists between stock volatility and idiosyncratic risk measures (over 0.95). Further, Table 4 reveals that the correlations among total risk and idiosyncratic risk and EMP are negative and significant, while both total and non-systematic risk and EE show no significant correlation, and EMP and EE show negative correlations.

[Insert TABLE 4 around here] 


\subsection{Multivariate Analyses and Discussion}

Table 5 reports the results of regression analysis. Models (1)-(3) show results from regressing CAMP_IDIO on the multidimensional CEP measures and control variables. Model (1) includes EMP and all control variables, showing that the coefficient on EMP is negative and statistically significant at the $1 \%$ level. Model (2) adds EE, the measure for carbon performance, and the result fails to show a significant association with firm risk, while the coefficient on EMP remains negative and significant. In Model (3), we add interaction between EMP and EE and the result of this interactive variable reveals a statistically significant positive relationship with CAMP_IDIO, while the EMP and carbon performance measures show statistically significant negative impact. The opposite sign of the interaction variable suggests a moderating effect of EE on the relationship between EMP and CAMP_IDIO. We conduct further multivariate tests to substantiate our findings. In particular, we replace CAMP_IDIO with the alternative idiosyncratic risk measures FAMA_IDIO (Models (4)-(6)) and CARHART_IDIO (Models (7)-(9)), and the results indicate that the negative relationship between EMP and firm risk is retained and the moderation effect of EE*EMP interaction also still exists.

We also regressed stock volatility (DEVRET) on a firm's EMP and EE (Models (10)-(12)) to find out the impact of multidimensional environmental performance on a firms' total risk. The results show that the coefficient on EMP is negative and statistically significant at the $1 \%$ level, while that on EOP is insignificant. Meanwhile, the significantly negative impact of the $E E^{*} E M P$ interaction variable is also retained. As for the control variables, the coefficients are generally consistent with expectations and relevant previous studies (e.g., Jo and Na, 2012; Cai et al., 2016).

\section{[Insert TABLE 5 around here]}

Overall, our results from the whole sample highlight two main findings. First, EMP shows a negative effect on the idiosyncratic and total risk of the sample firms, hence Hypothesis 1 is rejected. This is consistent with findings 
of previous studies (e.g., Salama et al., 2011; Cai et al., 2016) and the theoretical predictions that engaging in environmental management and activities can fulfil stakeholder expectation, in turn maximize firm value in the long-term, and provide a firm with environmental legitimacy.

Second, the relationship between EOP and firm risk is statistically insignificant, which supports Hypothesis 2. The finding that EMP and EOP have dissimilar effects on firm risk implies that investors react differently to outcome- and process-based environmental performance. This distinction is consistent with the findings of Endrikat et al. (2014) on the effect of EMP and EOP on CFP, which demonstrates that the CEP-CFP relationship varies according to the CEP dimensions.

The results of the EMP and EOP interactions provide for further insights on how investors recognize the multidimensional construct of CEP, indicating the moderating effect of EOP in the negative relationship between EMP and firm risk, which supports Hypothesis 3. Specifically, for companies with more carbon emissions and hence lower EOP scores (EE), their EMP has more impact on firm risk reduction; while for companies with good carbon performance already, their EMP's impact on firm risk reduction is moderated. The moderating effect of the interaction variable is broadly in line with the argument of relevant studies (e.g., Bird et al., 2007; Oikonomou et al., 2014) that investors do consider the mixed information exhibited from the CEP dimensions and simultaneously assess a firm's environmental outcomes and the efforts in environmental activities and processes. This finding suggests that for companies with poor carbon performance, managers' efforts and investment in environmental activities are rewarded by the investors with risk reduction; while for companies with good carbon performance, their efforts to further improve environmental management will not be considered as value added for shareholders.

The potential endogenous linkage between corporate environment performance and firm risk can be a concern. We incorporate a set of firmspecific control variables and industry and year dummies in our analysis to mitigate the concern that the observed CEP-risk relationship may be due to observable or unobservable factors that can affect both environment 
performance and firm risk. In addition, we adopt several alternative measures of firm risk to mitigate any concern over measurement error. Additionally, the use of lagged CEP in our research design potentially addresses the concern of reverse causality or simultaneity. To add more credence to our results, we employ an instrumental variable approach to further ameliorate endogeneity bias. Following previous studies (e.g., El Ghoul et al., 2011; Kim et al., 2014), we use the average CEP of other firms in the same industry as the instrumental variable.

The results are reported in Table 6 . We find significantly negative coefficients on the fitted value CEP for both total risk and idiosyncratic risk, indicating that the negative association between EMP and firm (idiosyncratic) risk holds when we control for endogeneity bias. Moreover, the Hausman test of endogeneity validates the requirement to correct for the endogeneity concern. The over-identification test and the test of weak instruments provide sufficient evidence that the selected instruments are appropriate.

\section{[Insert TABLE 6 around here]}

\subsection{Cross-Industry Analyses and Discussion}

Thus far, we have confirmed that firms with better environmental management associate with lower risk, while carbon performance does not show a significant impact. However, it is very likely that for different industries, EMP and carbon performance have different levels of influence on risk. In this section, we test the relationship between multidimensional CEP and a firm's idiosyncratic and total risk in manufacturing versus that in the service sector. In particular, we divide the firms into manufacturing and service sub-sectors according to their ICB code following Trumpp and Guenther (2017) and then re-run the tests for each sub-sector.

The descriptive statistics (see Appendix 2) indicate that service industries have, on average, better carbon performance (EE) than manufacturing, yet they have slightly worse EMP. Meanwhile, manufacturing 
firms are more likely to participate in the UNGC program than service-oriented firms, and they also have more intensive capital expenditure and R\&D investment, while service companies, on average, have better firm performance and cashflow.

Tables 7 and 8 present the multivariate regression results of the multidimensional CEP and firm risk relationship in the manufacturing and service sub-sectors, respectively. For manufacturing (Table 7), EMP shows a negative and significant association with idiosyncratic risk but carbon performance (EE) does not. The EE*EMP interaction variable also shows no significant influence. While both EMP and carbon performance show significant negative associations with total risk (EMP at the $1 \%$ level and EE at the $10 \%$ level), the interaction variable indicates a significant moderation effect. For service, results in Table 8 present that neither EMP or EE shows a statistically significant influence on a firms' idiosyncratic risk or stock volatility, while the interaction variable shows a positive and significant association.

\section{[Insert TABLE $7 \&$ TABLE 8 around here]}

Our empirical evidence supports Hypothesis 4 in the way the negative relationship between EMP and firm risk mainly comes from manufacturing, which is consistent with the observation of Cai et al. (2016) on environmental responsibility and firm risk. The intensive regulatory requirements and social awareness for environmental issues require manufacturing companies to enhance their environmental management and activities by engaging in various strategic environmental programs as part of risk management decisions. This provides the shareholders "insurance-like" protection (Godfrey, 2005; Godfrey et al., 2009). For service companies, the negative association between EMP/EOP and firm risk exists when considering the moderation effect of the EMP*EOP interactive variable, and EOP shows a stronger effect on firm risk reduction. This suggests that since service sector firms tend not to have intensive environmental issues in their operation processes, investors tend to give more consideration to the balance of input and output of environmental investment and activities. 


\section{Conclusions}

For 40 years, CEP has drawn increasing attention from regulators, academics, and practitioners. Although prior studies have tried to understand the importance of CEP to a firms' economic performance, few to date have considered the measurable economic consequences using firm-specific risk, and when measuring CEP, most have failed to consider its multidimensional nature. To contribute to and extend the existing literature, this study applies separate measures for the process- and outcome-based dimensions of CEP to examine the impact of each, as well as their interaction effects on a firm's idiosyncratic and total risk, using a comprehensive sample of UK companies from 2002 to 2013.

We find that environmental management performance - including a firm's environmental policy, objectives, processes, and monitoring - is associated with the firm's risk reduction, while its carbon emission performance failed to show any significant impact. Our results also reveal that EOP has a moderating effect on the relationship between negative EMP and firm risk. Our cross-industry investigation further reveals that the relationship between CEP and firm risk differs between the manufacturing and service sectors, and the negative association between EMP and a firm's idiosyncratic risk is more pronounced in manufacturing.

Benefiting from the insights drawn from multi-theoretical perspectives and focusing on the impact of CEP on idiosyncratic risk, our findings contribute to the finance, business strategy and environmental management literature in the following ways. This study extends the CEP literature by considering the multiple dimensions of CEP and examining their impact on firm risk, particularly firm-specific risk. Our findings indicating plurality of impacts of EMP and EOP on risk and their interactions support the argument that the result of a singular CEP dimension cannot transfer to the other one, so both dimensions should be considered in environmental performance studies (Trumpp et al., 2015). Our study demonstrates that financial markets tend to value firms' environmental management processes rather than their 
carbon emissions, which is contrary to findings of certain previous studies (e.g., Busch and Hoffmann, 2014). Our further investigation of the interaction effects of EMP and EOP shows that investors consider the full picture of a firm's environmental performance, which emphasizes the importance of considering the complexity of CEP in academic scholarship. For firms with higher levels of carbon emissions, engaging in environmental management will offer greater reputational benefit and insurance-like protection to shareholders (Godfrey et al., 2009; Cai et al., 2016), which is consistent with legitimacy theory. By contrast, for firms with better carbon performance, the benefits of investing in environmental management may fall flat or even backfire owing to a waste of core business resources (Jo and $\mathrm{Na}, 2012$ ), as agency theory suggests. This overall supports the suggestions of value maximization through stakeholder synergy from extended stakeholder perspectives (e.g., Jensen, 2001; Tantalo and Priem, 2016). Finally, our findings from cross-industry investigation extend our understanding of the impact of CEP across sectors on the association between the dimensions of CEP and firm risk. The findings support the premise that stakeholders in manufacturing may have a higher awareness of the impact of CEP on risk because of their supposed higher environmental impact (Trumpp and Guenther, 2015). This highlights the importance of environmental management to risk control for managers in manufacturing industries. For the service sector, which has been somewhat neglected by previous CEP studies, our findings suggest that investors care more about the full picture of a company's environmental performance; thus managers need to consider the trade-off between the investment in the environmental management and its output.

Drawing insights from the UK experience, our findings have important implications for managers and regulators with regard to both decision-making and policy-making, both in the UK and worldwide. For managers, strategic environmental management and improvement of environmental policies and processes should be included in firms' risk management agendas. Particularly for companies with poor carbon performance or those in manufacturing sector, engagement in strategic environmental management and investment 
in environmental activities will benefit a broad spectrum of stakeholders and provide protection for investors in the longer term.

For regulators and public policy-makers, our findings suggest that the implementation of environmental policy should not only focus on the reporting of quantitative environmental indicators, but also on the establishment of appropriate environmental management systems and the development of environmental strategies. Currently the key environmental performance indicators suggested by the 'Environmental Reporting Guidelines' for UK companies are predominately quantitative measures of environmental operational output. Our findings propose that evaluating business environmental management processes and activities should also be incorporated into environmental policies. This information is important for investors and other stakeholders as it ensures the quality and reliability of output measures and can help reduce greenhouse emissions and other environmental issues in the long run.

As with most empirical work, our study has limitations that should be addressed in future research. Firstly, due to data limitations, our proxies for EMP were created based on the KPIs in the ASSET4 database following Trumpp et al. (2015). Future studies might usefully employ a more comprehensive set of EMP measures using content analysis. Secondly, like most scholarship of this nature, we examine the environmental performance from a quantitative perspective. Our proxies of environmental performance may not reflect actual corporate management practice. In this case, future research may benefit from deeper insights by conducting interviews and case studies with managers and directors to illuminate their activity more vividly. Thirdly, our study mainly focuses on UK firms, so the findings may not be meaningfully extrapolated to other nations with different regulatory and industrial contexts. It would be enlightening were future research to take on the challenge of examining multidimensional CEP relationships with firm risk across a multi-country context that controls for variations in institutional and regulatory contexts. Finally, while our study recognizes the importance of considering the multi-dimensional nature of CEP, we have only considered 
two dimensions. It would also be interesting for future research to extend this to other dimensions and consider the reactions of specified stakeholder groups, such as employees and customers. 


\section{References}

Al-Hadi, A., Chatterjee, B., Yanftian, A., Taylor, G., \& Monzur, H. M. (2019). Corporate social responsibility performance, financial distress and firm life cycle: evidence from Australia. Accounting and Finance, 59(2), 961989. https://doi.org/10.1111/acfi.12277

Bansal, P. \& Clelland, I. (2004). Talking trash: Legitimacy, impression management, and unsystematic risk in the context of the natural environment. The Academy of Management Journal, 47(1), 93-103.

Barnea, A. \& Rubin, A. (2010). Corporate social responsibility as a conflict between shareholders. Journal of Business Ethics, 97(1), 71-86. https://doi.org /10.1007/s10551-010-0496-z

Benlemlih, M., Shaukat, A., Qiu Y., \& Trojanowski, G. (2018). Environmental and social disclosures and firm risk. Journal of Business Ethics, 152(3), 613-626. https://doi.org/10.1007/s10551-016-3285-5

Bhattacharyya, A., \& Cummings, L. (2015). Meauring corporate enviornmental performance - Stakeholder engagement evaluation. Business Strategy and the Environment, 24, 309-325. https://doi.org/10.1002/bse.1819

Bird, R., Hall, A. D., Momente, F. \& Reggiani, F. (2007). What corporate social responsibility activities are valued by the market? Journal of Business Ethics, 76, 189-206. https://doi.org/10.1007/s10551-006-9268-1

Bouslah, K., Kryzanowski, L., \& M'Zali, B. (2013). The impact of the dimensions of social performance on firm risk. Journal of Banking and Finance, 37(4), 1258-1273. https://doi.org/10.1016/j.jbankfin.2012.12.004

Busch, T., \& Hoffmann, V. H. (2011). How hot is your bottom line? Linking carbon and financial performance. Business \& Society, 50(2), 233-265. https://doi.org/10.1177/0007650311398780

Cai, L., Cui, J., \& Jo, H. (2016). Corporate environmental responsibility and firm risk. Journal of Business Ethics, 139(3), 563-594. https://doi.org/10.1007/s10551-015-2630-4

Cheng, B., Ioannou, I., \& Serafeim, G. (2014). Corporate social responsibility and access to finance. Strategic Management Journal, 35, 1-23. https://doi.org/10.1002/smj.2131

Choi, J., \& Wang, H. (2009). Stakeholder relations and the persistence of 
corporate financial performance. Strategic Management Journal, 30, 895907. https://doi.org/10.1002/smj.759

Clarkson, P. M., Li, Y., Richardson, G. D., \& Vasvari, F. P. (2011). Does it really pay to be green? Determinants and consequences of proactive environmental strategies. Journal of Accounting and Public Policy, 30(2), 122-144. https://doi.org/10.1016/j.aos.2007.05.003

Clemens, B., \& Bakstran, L. (2010). A framework of theoretical lenses and strategic purposes to describe relationships among firm environmental strategy, financial performance, and environmental performance. Management Research Review, 33(4), 393-405.

DECC (2015). UK progress towards GHG emissions reduction targets. Department of Energy \& Climate Change. Department of Energy \& Climate Change. Retrieved from https://assets.publishing.service.gov.uk/government/uploads/system/uplo ads/attachment_data/file/414241/20150319_Progress_to_emissions_red uctions_targets_final.pdf.

DEFRA (2011). Environmental key performance indicators: Reporting guidelines for UK business. Department for Environment Food \& Rural Affairs. Retrieved from https://assets.publishing.service.gov.uk/government/uploads/system/uplo ads/attachment_data/file/69281/pb11321-envkpi-guidelines-060121.pdf.

DEFRA (2012). Small business user guide: Guidance on how to measure and report your greenhouse gas emissions. Department for Environment Food \& Rural Affairs. Retrieved from https://assets.publishing.service.gov.uk/government/uploads/system/uplo ads/attachment_data/file/69494/pb13310-ghg-small-business-guide.pdf.

DEFRA (2013). Environmental reporting guidelines: including streamlined energy and carbon reporting requirements. Department for Environment Food \& Rural Affairs. Retrieved from https://assets.publishing.service.gov.uk/government/uploads/system/uplo ads/attachment_data/file/791529/Env-reportingguidance_inc_SECR_31March.pdf.

DEFRA (2018). The national adaption programme and the third stategy for climate adaptation reporting - Making the country resilient to a changing 
climate. Department for Environment Food \& Rural Affairs. Retrieved from

https://assets.publishing.service.gov.uk/government/uploads/system/uplo ads/attachment_data/file/727252/national-adaptation-programme2018.pdf.

Delmas, M. A., Etzion, D., \& Nairn-Birch, N. (2013). Triangulating environmental performance: What do corporate social responsibility ratings really capture? Academy of Management Perspectives, 27(3), 255-267. http://dx.doi.org/10.5465/amp.2012.0123

Dobler, M., Lajili, K., \& Zéghal, D. (2014). Environmental performance, environemtnal risk and risk management. Business Strategy and the Environment, 23, 1-17. https://doi.org/10.1002/bse.1754

El Ghoul, S., Guedhami, O., Kwok, C. C. Y., \& Mishra, D. R. (2011). Does corporate social responsibility affect the cost of capital? Journal of Banking and Finance, 35(9), 2388-2406. https://doi.org/10.1016/j.jbankfin.2011.02.007

Elmagrhi, H. M., Ntim, G. C., Elamer, A. A., \& Zhang, Q. (2019). A study of environmental policies and regulations, governance structures, and environmental performance: The role of female directors. Business Strategy and the Environment, 28, 206-220. https://doi.org/10.1002/bse.2250

Endrikat, J., Guenther, E., \& Hoppe, H. (2014). Making sense of conflicting empirical findings: A meta-analytic review of the relationship between corporate environmental and financial performance. European $\begin{array}{lll}\text { Management } \quad \text { Journal, } & \text { 32(5), }\end{array}$ https://doi.org/10.1016/j.emj.2013.12.004

Escrig-Olmedo, E., Muñoz-Torres, M. J., Fernández-Izquierdo, M. Á., \& Rivera-Lirio, J. M. (2017). Measuring corporate environmental performance: A methodology for sustainable development. Business Strategy and the Environment, 26(2), 142-162. https://doi.org/10.1002/bse.1904

Fujii, H., Iwata, K., Kaneko, S., \& Managi, S. (2013). Corporate environmental and economic performance of Japanese manufacturing firms: Empirical study for sustainable development. Business Strategy and the 
Environment, 22(3), 187-201. https://doi.org/10.1002/bse.1747

Gatimbu, K. K., Ogada, M. J., Budambula, N. \& Kariuki, S. (2018). Environmental sustainability and financial performance of the small-scale tea processors in Kenya. Business Strategy and the Environment, 27(8), 1765-1771. https://doi: 10.1002/bse.2243

Godfrey, P. C. (2005). The relationship between corporate philanthropy and shareholder wealth: A risk management perspective. The Academy of $\begin{array}{lll}\text { Management } \quad \text { Review, } & \text { 777 }\end{array}$ https://doi.org/10.5465/amr.2005.18378878

Godfrey, P. C., Merrill, C. B., \& Hansen, J. M. (2009). The relationship between corporate social responsibility and shareholder value: An empirical test of the risk management hypothesis. Strategic Management Journal, 30(4), 425-445. https://doi.org/10.1002/smj.750

Goss, A., \& Roberts, G. S. (2011). The impact of corporate social responsbility on the cost of bank loans. Journal of Banking \& Finance, 35, 1794-1810. https://doi.org/10.1016/j.jbankfin.2010.12.002

Hang, M., Geyer-Klingeberg, J. \& Rathgeber, A. W. (2019). It is merely a matter of time: A meta-analysis of the causality between environmental performance and financial performance. Business Strategy and the Environment, 28(2), 257-273. https://doi.org/10.1002/bse.2215

Haque, F., \& Ntim, C. G. (2018). Environmental policy, sustainable development, governance mechanisms and environmental performance. Business Strategy and the Environment, 27(3), 415-435. https://doi.org/10.1002/bse.2007

Harjoto, M., \& Laksmana, I. (2018). The impact of corporate social responsibility on risk taking and firm value. Journal of Business Ethics, 151, 353-373. https://doi.org/10.1007/s10551-016-3202-y

Hart, S. L. (1995). A natural-resource-based view of the firm. The Academy of Management Review, 20(4), 986-1014. https://doi.org/10.5465/amr.1995.9512280033

Hart, S. L., \& Ahuja, G. (1996). Does it pay to be green? An empirical examination of the relationship between emission reduction and firm performance. Business Strategy and the Environment, 5, 30-37.

Hartmann, J., \& Vachon, S. (2018). Linking environmental management to 
environmental performance: The interactive role of industry context. Business Strategy and the Environment, 27, 359-374. http://doi.org/ 10.1002/bse.2003

Heinkel, R., Kraus, A., \& Zechner, J., (2001). The effect of green investment on corporate behaviour. Journal of Financial and Quantitative Analysis, 36, 431-449.

Hong, H., \& Kacperczyk, M. (2009). The price of sin: The effects of social norms on markets. Journal of Financial Economics, 93, 15-36. https://doi.org/10.1016/j.jfineco.2008.09.001

Horvathova, E. (2012). The impact of environmental performance on firm performance: Short-term costs and long-term benefits? Ecological Economics, 84, 91-97. https://doi.org/10.1016/j.ecolecon.2012.10.001

llinitch, A. Y., Soderstrom, N. S., \& Thomas, T. E. (1998). Measuring corporate environmental performance. Journal of Accounting Public Policy, 17(4/5), 383-408.

Jensen M.C. (2001). Value maximization, stakeholder theory, and the corporate objective function. Journal of Appliced Corporate Finance, 14(3), 8-21.

Jensen, M. C., \& Meckling, W. H. (1976). Theory of the firm: Managerial behavior, agency costs and ownership structure. Journal of Financial Economics, 3, 305-360.

Jo, H., \& Harjoto, M. A. (2011). Corporate governance and firm value: The impact of corporate social responsibility. Journal of Business Ethics, 103(3), 351-383. https://doi.org/10.1007/s10551-011-0869-y

Jo, H., \& Harjoto, M. A. (2012). The causal effect of corporate governance on corporate social responsibility. Journal of Business Ethics, 106(1), 53-72. https://doi.org/10.1007/s10551-011-1052-1

Jo, H., \& Na, H. (2012). Does CSR reduce firm risk? Evidence from controversial industry sectors. Journal of Business Ethics, 110(4), 441457. https://doi.org/10.1007/s10551-012-1492-2

Jones, M. T. (1995). Instrumental stakeholder theory: A synthesis of ethics and economics. The Academy of Management Review, 20(2), 404-437.

Jung, E. J., Kim, J. S., \& Rhee, S. K. (2001). The measurement of corporate environmental performance and its application to the analysis of 
efficiency in oil industry. Journal of Cleaner Production, 9(6), 551-563. https://doi.org/10.1016/S0959-6526(01)00011-7

Kim, Y., Li, H., \& Li, S. (2014). Corporate social responsibility and stock price crash risk. Journal of Banking \& Finance, 43, 1-13. https://doi.org/10.1016/j.jbankfin.2014.02.013

Konar, S., \& Cohen, M.A. (2001). Does the market value environmental performance. Review of Economics and Statistics, 83, 281-289.

Lee, D. D., \& Faff, R. W. (2009). Corporate sustainability performance and idiosyncratic risk: A global perspective. The Financial Review, 44(2), 213237. https://doi.org/10.1111/j.1540-6288.2009.00216.x

Mackey, A., Mackey, T. B., \& Barney, F. B., (2007). Corporate social responsibility and firm performance: investor preferences and corporate strategies. Academy of Management Review, 32, 817-835.

Merton, R. C. (1987). A simple model of capital market equilibrium with incomplete information. The Journal of Finance, XLII (3), 483-510.

Misani, N., \& Pogutz, S. (2015). Unraveling the effects of environmental outcomes and processes on financial performance: A non-linear approach. Ecological Economics, 109, 150-160. http://dx.doi.org/10.1016/j.ecolecon.2014.11.010

Moussa, T., Allam, A., Elbanna, S. \& Bani-Mustafa, A. (2019). Can board environmental orientation improve U.S. firms' carbon performance? The mediating role of carbon strategy. Business Strategy and the Environment. [Forthcoming] https://doi.org/10.1002/bse.2351

Nawrocka, D., \& Parker, T. (2009). Finding the connection: Environmental management systems and environmental performance. Journal of Cleaner Production, 17, 6001-6607. https://doi.org/10.1016/j.jclepro.2008.10.003

Ntim, C. G. \& Soobaroyen, T. (2013). Black economic empowerment disclosures by South African listed corporations: The influence of ownership and board characteristics. Journal of Business Ethics, 116, 121-138. https:// doi.org/10.1007/s10551-012-1446-8

Oikonomou, I., Brooks, C., \& Pavelin, S. (2014). The financial effects of uniform and mixed corporate social performance. Journal of Management Studies, 51(6), 898-925. https://doi.org/10.1111/joms.12064 
Rasche, A., Waddock, S., \& Mclntosh, M. (2013). The United Nations Global Compact: Retrospect and prospect. Business \& Society, 52(1), 6-30. https://doi.org/10.1177/0007650312459999

Ren, S., He, D., Zhang, T. \& Chen, X. (2019). Symbolic reactions or substantive pro-environmental behaviour? An empirical study of corporate environmental performance under the government's environmental subsidy scheme. Business Strategy and the Enironment, 28(6), 1-19. https://doi.org/10.1002/bse.2308

Ross, S. (1973). The economic theory of agency: The principal's problem. American Economic Review, 63(2), 134-139.

Salama, A., Anderson, K. \& Toms, J. S. (2011). Does community and environmental responsibility affect firm risk? Evidence from UK panel data 1994-2006. Business Ethics: A European Review, 20(2), 192-204. https://doi.org/10.1111/j.1467-8608.2011.01617.x

Sarkis, J. \& Cordeiro, J. J. (2001). An empirical evaluation of environmental efficiencies and firm performance: Pollution prevention versus end-ofpipe practice. European Journal of Operational Research, 135, 102-113.

Shahab, Y., Ntim, C. G., Chengang, Y., Ullah, F., \& Fosu, S. (2018). Environmental policy, environmental performance, and financial distress in China: Do top management team characteristics matter? Business Strategy and the Environment, 27(8), 1635-1652. https://doi.org/10.1002/bse.2229

Shahab, Y., Ntim, C. G., \& Ullah, F. (2019). The brighter side of being socially responsible: CSR ratings and financial distress among Chinese state and non-state owned firms. Applied Economics Letters, 26(3), 180-186.

Sharfman, M. P., \& Fenando, C. S. (2008). Environmental risk management and the cost of capital. Strategic Management Journal, 29, 569-592. https://doi.org/10.1002/smj.678

Sharma, S., \& Vredenburg, H. (1998). Proactive corporate environmental strategy and the development of competitively valuable organizational capabilities. Strategic Managment Journal, 19(8), 729-753.

Soleimani, A., Schneper, W. D., \& Newburry, W. (2014). The impact of stakeholder power on corporate reputation: A cross-country corporate governance perspective. Organization Science, 25(4), 991-1008. 
https://doi.org/10.1287/orsc.2013.0889

Stellner, C., Klein, C., \& Zwergel, B. (2015). Corporate social responsibility and eurozone corporate bonds: The moderating role of country sustainability. Journal of Banking and Finance, 59, 538-549. https://doi.org/10.1016/j.jbankfin.2015.04.032

Suchman, M.C. (1995). Managing legitimacy: Strategic and institutional approaches. Academy of Management Review, 20, 571-610.

Tantalo, C. \& Priem, R. L. (2016), Value creation through stakeholder synergy. Strategic Management Journal, 37, 314-329. https://doi:10.1002/smj.2337

Thomson-Reuters (2015). Research Data. Retrieved from http://financial.thomsonreuters.com/ [16.04.2016].

Trumpp, C., \& Guenther, T. (2017). Too little or too much? Exploring Ushaped relationships between corporate environmental performance and corporate financial performance. Business Strategy and the Environment, 26, 49-68. https://doi.org/10.1002/bse.1900

Trumpp, C., Endrikat, J., Zopf, C., \& Guenther, E. (2015). Definition, conceptualization, and measurement of corporate environmental performance: A critical examination of a multidimensional construct. Journal of Business Ethics, 126(2), 185-204. https://doi.org/10.1007/s10551-013-1931-8

Van Slyke, D. M. (2006). Agents or stewards: Using theory to understand the government-nonprofit social service contracting relationship. Journal of Public Administration Research and Theory, 17, 157-187. https://doi.org/10.1093/jopart/mul012

Walls, J. L., Phan, P. H., \& Berrone, P. (2011). Measuring environmental strategy: Costruct, development, reliability, and validity. Business \& Society, 51(1), 71-115. https://doi.org/10.1177/0007650310394427

Xie, S., \& Hayase, K. (2007). Corporate environmental performance evaluation: A measurement model and a new concept. Business Strategy and the Environment, 16(2), 148-168. https://doi.org/10.1002/bse.493

Ziegler, A., Busch, T., \& Hoffmann, V. H. (2011). Disclosed corporate responses to climate change and stock performance: An international empirical analysis. Energy Economics, 33(6), 1283-1294. 
https://doi.org/10.1016/j.eneco.2011.03.007 
Table 1 Sample description

\begin{tabular}{|c|c|c|c|c|c|c|c|c|c|c|c|c|c|}
\hline & \multicolumn{12}{|c|}{ Firms per year } & \multirow[t]{2}{*}{$\begin{array}{l}\text { Firm-years } \\
\text { Total }\end{array}$} \\
\hline & 2002 & 2003 & 2004 & 2005 & 2006 & 2007 & 2008 & 2009 & 2010 & 2011 & 2012 & 2013 & \\
\hline \multicolumn{14}{|l|}{ Manufacturing industries } \\
\hline Basic Materials (ICB 1) & 1 & 2 & 5 & 6 & 7 & 10 & 13 & 14 & 16 & 20 & 18 & 23 & 135 \\
\hline Industrials (ICB 2) & 6 & 7 & 9 & 20 & 27 & 36 & 37 & 46 & 49 & 55 & 55 & 57 & 404 \\
\hline Health Care (ICB 4) & 3 & 3 & 4 & 4 & 4 & 4 & 4 & 5 & 6 & 5 & 6 & 7 & 55 \\
\hline Utilities (ICB 7) & 2 & 5 & 5 & 6 & 7 & 6 & 7 & 7 & 7 & 7 & 7 & 7 & 73 \\
\hline $\begin{array}{l}\text { Technology Hardware \& } \\
\text { Equipment (ICB 9570) }\end{array}$ & 0 & 0 & 0 & 1 & 1 & 1 & 1 & 1 & 1 & 1 & 2 & 2 & 11 \\
\hline Manufacturing industries total & 15 & 20 & 30 & 53 & 62 & 77 & 84 & 99 & 108 & 119 & 125 & 132 & 924 \\
\hline Financials (ICB 8) & 5 & 6 & 13 & 19 & 28 & 33 & 35 & 40 & 39 & 43 & 42 & 49 & 352 \\
\hline $\begin{array}{l}\text { Software \& Computer Services } \\
\text { (ICB 9530) }\end{array}$ & 0 & 0 & 0 & 0 & 0 & 0 & 0 & 2 & 2 & 1 & 2 & 3 & 10 \\
\hline Service industries total & 11 & 12 & 22 & 34 & 50 & 59 & 66 & 82 & 86 & 89 & 91 & 106 & 708 \\
\hline Full sample & 26 & 32 & 52 & 87 & 112 & 136 & 150 & 181 & 194 & 208 & 216 & 238 & 1632 \\
\hline
\end{tabular}


Table 2 Variables definitions

\begin{tabular}{|c|c|c|c|}
\hline Category & Variables & Definitions & Label \\
\hline \multirow[t]{2}{*}{$\begin{array}{l}\text { Dependent } \\
\text { variable }\end{array}$} & $\begin{array}{l}\text { Firm risk (Total } \\
\text { risk) }\end{array}$ & $\begin{array}{l}\text { Annualized stock volatility measured as the } \\
\text { standard deviation of daily stock returns }\end{array}$ & DEVRET \\
\hline & $\begin{array}{l}\text { Firm risk (non- } \\
\text { systematic risk) }\end{array}$ & $\begin{array}{l}\text { Idiosyncratic risk measured as the } \\
\text { standard deviation of residuals from } \\
\text { CAPM, based on daily stock return } \\
\text { Idiosyncratic risk measured as the } \\
\text { standard deviation of residuals from FAMA } \\
\text { three-factor model, based on daily stock } \\
\text { return } \\
\text { Idiosyncratic risk measured as the } \\
\text { standard deviation of residuals from } \\
\text { CARHART four-factor model, based on } \\
\text { daily stock return }\end{array}$ & CARHART_IDIO \\
\hline \multirow[t]{2}{*}{$\begin{array}{l}\text { Independent } \\
\text { variable }\end{array}$} & $\begin{array}{l}\text { Environmental } \\
\text { management } \\
\text { performance }\end{array}$ & $\begin{array}{l}\text { The average score of the firms' } \\
\text { environmental management activities } \\
\text { indicators from ASSET4 }\end{array}$ & EMP \\
\hline & $\begin{array}{l}\text { Environmental } \\
\text { operational } \\
\text { performance }\end{array}$ & $\begin{array}{l}\mathrm{EOP} \text { is measured by net sales divided by } \\
\mathrm{CO}_{2} \text { and } \mathrm{CO}_{2} \text {-equivalents emissions }\end{array}$ & EE \\
\hline \multirow[t]{9}{*}{$\begin{array}{l}\text { Control } \\
\text { variable }\end{array}$} & $\begin{array}{l}\text { Firm } \\
\text { Performance }\end{array}$ & $\begin{array}{l}\text { Return on sales, the ratio of earnings } \\
\text { before interest and taxes to net sales }\end{array}$ & ROS \\
\hline & $\begin{array}{l}\text { Corporate } \\
\text { Governance } \\
\text { Score }\end{array}$ & ASSET4 Corporate Governance Score & CGSCORE \\
\hline & $\begin{array}{l}\text { UN Global } \\
\text { Compact }\end{array}$ & $\begin{array}{l}\text { Dummy variable: }=1 \text { if a firm adhered to the } \\
\text { United Nations' Global Compact within a } \\
\text { year, and }=0 \text { otherwise }\end{array}$ & UNGC \\
\hline & R\&D intensity & The ratio of R\&D expenses to total sales & $R \& D$ \\
\hline & Firm size & $\begin{array}{l}\text { The company size is measured by the } \\
\text { natural logarithm of total assets }\end{array}$ & SIZE \\
\hline & Cash flow & The ratio of net cash flow to total sales & CASHFLOW \\
\hline & $\begin{array}{l}\text { Capital } \\
\text { intensity }\end{array}$ & $\begin{array}{l}\text { Capital expenditures divided by beginning } \\
\text { of the year total assets }\end{array}$ & CAPITAL \\
\hline & Leverage & Total debt divided by total assets & LEVERAGE \\
\hline & Growth & $\begin{array}{l}\text { Change in total assets divided by } \\
\text { beginning of period total assets }\end{array}$ & GROWTH \\
\hline
\end{tabular}

Note: This table gives the definition and description of each variable used in the estimation. 
Table 3 Descriptive statistics

\begin{tabular}{lcccccc}
\hline Variable & Mean & Median & Std dev & Minimum & Maximum & $\mathrm{N}$ \\
\hline DEVRET & 0.021 & 0.018 & 0.011 & 0.006 & 0.104 & 1632 \\
CAMP_IDIO (thousand) & 17.601 & 14.891 & 9.015 & 5.819 & 64.330 & 1632 \\
FAMA_IDIO (thousand) & 16.897 & 14.345 & 8.880 & 3.364 & 98.371 & 1632 \\
CARHART_IDIO (thousand) & 16.866 & 14.318 & 8.847 & 3.353 & 97.384 & 1632 \\
EMP & 55.068 & 54.143 & 11.860 & 23.952 & 86.494 & 1632 \\
EE & 0.707 & 0.175 & 1.976 & 0.001 & 20.239 & 1581 \\
ROS (\%) & 18.193 & 9.900 & 67.328 & -587.257 & 882.556 & 1632 \\
UNGC & 0.183 & 0.000 & 0.387 & 0.000 & 1.000 & 1632 \\
CGSCORE & 78.713 & 82.480 & 14.010 & 5.300 & 97.330 & 1632 \\
SIZE & 15.215 & 14.848 & 1.860 & 10.402 & 21.596 & 1632 \\
GROWTH & 0.088 & 0.052 & 0.221 & -0.419 & 1.519 & 1632 \\
LEVERAGE & 0.242 & 0.229 & 0.178 & 0.000 & 1.672 & 1632 \\
CASHFLOW (\%) & 16.677 & 13.230 & 15.579 & -44.500 & 78.660 & 1632 \\
CAPITAL & 0.048 & 0.033 & 0.051 & 0.000 & 0.422 & 1632 \\
R\&D (\%) & 1.177 & 0.000 & 4.015 & 0.000 & 47.990 & 1632 \\
\hline N\&)
\end{tabular}

Note: This table reports univariate statistics (number of observations, mean, standard deviation, minimum, maximum). The sample consists of 1,632 firm-year observations, covering all firms listed on the London Stock Exchange using the ASSET4 database over the 2002-2013 period. The firm's carbon emissions and environmental management score are taken from the ASSET4 database, which are used to calculate EE and EMP. The definitions of variables are presented in Table 2. 
Table 4 Summary of bivariate correlations

\begin{tabular}{|c|c|c|c|c|c|c|c|c|c|c|c|c|c|c|c|c|}
\hline No & Variables & $(1)$ & $(2)$ & (3) & $(4)$ & $(5)$ & (6) & $(7)$ & $(8)$ & (9) & $(10)$ & $(11)$ & $(12)$ & (13) & $(14)$ & (15) \\
\hline (1) & DEVRET & 1 & & & & & & & & & & & & & & \\
\hline (2) & CAMP_IDIO & $0.950^{* * *}$ & 1 & & & & & & & & & & & & & \\
\hline (3) & FAMA_IDIO & $0.954^{* * *}$ & $0.980^{* * *}$ & 1 & & & & & & & & & & & & \\
\hline (4) & CARHART_IDIO & $0.953^{* * *}$ & $0.981^{* * *}$ & $1.000^{* * *}$ & 1 & & & & & & & & & & & \\
\hline (5) & EMP & $-0.075^{\star * *}$ & $-0.157^{* * *}$ & $-0.158^{* * *}$ & $-0.158^{* * *}$ & 1 & & & & & & & & & & \\
\hline (6) & $\mathrm{EE}$ & 0.036 & 0.002 & -0.003 & -0.002 & $-0.134^{* * *}$ & 1 & & & & & & & & & \\
\hline (7) & ROS & $-0.141^{* \star *}$ & $-0.159^{* * *}$ & $-0.153^{\star * *}$ & $-0.154^{* * *}$ & $-0.045^{\star}$ & 0.019 & 1 & & & & & & & & \\
\hline (9) & CGSCORE & $-0.112^{* * *}$ & $-0.149^{* * *}$ & $-0.146^{* * *}$ & $-0.146^{* * *}$ & $0.382^{* * *}$ & -0.034 & 0.024 & $0.157^{* * *}$ & 1 & & & & & & \\
\hline (10) & SIZE & $-0.046^{*}$ & $-0.187^{* * *}$ & $-0.177^{\star \star *}$ & $-0.179^{\star * *}$ & $0.562^{* * *}$ & $0.131^{* * *}$ & -0.015 & $0.396^{\star * *}$ & $0.199 * * *$ & 1 & & & & & \\
\hline (11) & GROWTH & 0.017 & -0.027 & -0.023 & -0.025 & $-0.077^{* * *}$ & 0.010 & $0.190^{* * *}$ & 0.007 & $-0.042^{*}$ & $0.065^{\star * *}$ & 1 & & & & \\
\hline$(12)$ & LEVERAGE & 0.024 & $0.063^{* *}$ & $0.051^{* *}$ & $0.052^{* *}$ & $0.042^{*}$ & $-0.192^{* * *}$ & 0.022 & $-0.046^{*}$ & 0.017 & 0.002 & $-0.071^{* * *}$ & 1 & & & \\
\hline (13) & CASHFLOW & $-0.084^{* * *}$ & $-0.111^{* * *}$ & $-0.105^{\star * *}$ & $-0.106^{* * *}$ & $-0.077^{* * *}$ & -0.028 & $0.236^{* * *}$ & $0.082^{* * *}$ & -0.029 & 0.031 & $0.172^{* * *}$ & -0.004 & 1 & & \\
\hline (14) & CAPITAL & 0.031 & 0.029 & 0.039 & 0.037 & 0.009 & $-0.244^{\star * *}$ & $0.141^{* * *}$ & $0.071^{* * *}$ & -0.036 & $-0.094^{\star * *}$ & $0.259^{* * *}$ & $0.074^{\star \star \star}$ & $0.269^{* * *}$ & 1 & \\
\hline$(15)$ & R\&D & $-0.083^{* * *}$ & $-0.056^{* *}$ & $-0.061^{* *}$ & $-0.061^{* *}$ & -0.012 & $-0.062^{* *}$ & -0.028 & -0.037 & -0.024 & $-0.043^{*}$ & -0.007 & $-0.091^{* * *}$ & 0.005 & $-0.090^{* * *}$ & 1 \\
\hline
\end{tabular}

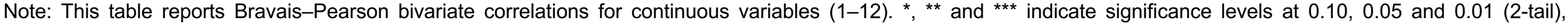
respectively. The definitions of variables are presented in Table 2. 
Table 5 Relationship between multi-dimensional environmental performance and firm risk

\begin{tabular}{|c|c|c|c|c|c|c|c|c|c|c|c|c|}
\hline & $\begin{array}{c}\text { CAPM_IDIO } \\
(\mathrm{t})\end{array}$ & $\begin{array}{c}\text { CAPM_IDIO } \\
(\mathrm{t})\end{array}$ & $\begin{array}{c}\text { CAPM_IDIO } \\
(\mathrm{t})\end{array}$ & $\begin{array}{c}\text { FAMA_IDIO } \\
(\mathrm{t})\end{array}$ & $\begin{array}{c}\text { FAMA_IDIO } \\
(\mathrm{t})\end{array}$ & $\begin{array}{c}\text { FAMA_IDIO } \\
(\mathrm{t})\end{array}$ & $\begin{array}{c}\text { CARHART_IDIO } \\
(\mathrm{t})\end{array}$ & $\begin{array}{c}\text { CARHART_IDIO } \\
(\mathrm{t})\end{array}$ & $\begin{array}{c}\text { CARHART_IDIO } \\
(\mathrm{t})\end{array}$ & $\begin{array}{c}\text { DEVRET } \\
(\mathrm{t})\end{array}$ & $\begin{array}{c}\text { DEVRET } \\
(\mathrm{t})\end{array}$ & $\begin{array}{c}\text { DEVRET } \\
(\mathrm{t})\end{array}$ \\
\hline & (1) & (2) & (3) & (4) & (5) & (6) & (7) & (8) & (9) & (10) & (11) & (12) \\
\hline \multirow[t]{2}{*}{$\mathrm{EMP}_{\mathrm{t}-1}$} & $-0.073^{\star \star *}$ & $-0.075^{\star \star \star}$ & $-0.092^{* * *}$ & $-0.085^{\star \star *}$ & $-0.090^{* * *}$ & $-0.106^{* \star *}$ & $-0.084^{* * *}$ & $-0.089^{* \star *}$ & $-0.105^{\star \star \star}$ & $-0.000^{* \star \star}$ & $-0.000^{* \star *}$ & $-0.000^{\star \star *}$ \\
\hline & $(-3.56)$ & $(-3.48)$ & $(-4.25)$ & $(-4.00)$ & $(-3.96)$ & $(-4.68)$ & $(-3.97)$ & $(-3.92)$ & $(-4.64)$ & $(-3.88)$ & $(-3.70)$ & $(-4.47)$ \\
\hline \multirow[t]{2}{*}{$\mathrm{EE}_{\mathrm{t}-1}$} & & -0.076 & $-2.095^{\star \star \star}$ & & -0.117 & $-2.058^{* * *}$ & & -0.117 & $-2.051^{* * *}$ & & -0.000 & $-0.002^{* * *}$ \\
\hline & & $(-0.59)$ & $(-4.96)$ & & $(-0.92)$ & $(-5.19)$ & & $(-0.93)$ & $(-5.19)$ & & $(-0.37)$ & $(-4.91)$ \\
\hline \multirow[t]{2}{*}{$E E_{t-1} * E M_{t-1}$} & & & $0.040^{* * *}$ & & & $0.039^{* * *}$ & & & $0.039^{* * *}$ & & & $0.000^{* * *}$ \\
\hline & & & $(4.48)$ & & & $(4.65)$ & & & $(4.65)$ & & & $(4.48)$ \\
\hline \multirow[t]{2}{*}{$\operatorname{ROS}_{t-1}$} & $-0.009^{* * *}$ & $-0.009^{* * *}$ & $-0.008^{* * *}$ & $-0.008^{* * *}$ & $-0.008^{* * *}$ & $-0.007^{* *}$ & $-0.009^{* \star *}$ & $-0.008^{* * *}$ & $-0.007^{\star * *}$ & $-0.000^{\star * *}$ & $-0.000^{\star * *}$ & $-0.000^{* *}$ \\
\hline & $(-2.86)$ & $(-2.72)$ & $(-2.67)$ & $(-2.75)$ & $(-2.63)$ & $(-2.56)$ & $(-2.83)$ & $(-2.70)$ & $(-2.65)$ & $(-2.79)$ & $(-2.63)$ & $(-2.51)$ \\
\hline \multirow[t]{2}{*}{$U N G C_{t-1}$} & -0.703 & -0.668 & -0.538 & -0.571 & -0.538 & -0.413 & -0.569 & -0.537 & -0.412 & -0.001 & -0.000 & -0.000 \\
\hline & $(-1.42)$ & $(-1.33)$ & $(-1.08)$ & $(-1.13)$ & $(-1.05)$ & $(-0.81)$ & $(-1.13)$ & $(-1.05)$ & $(-0.81)$ & $(-0.93)$ & $(-0.80)$ & $(-0.56)$ \\
\hline \multirow[t]{2}{*}{ CGSCORE $_{t-1}$} & $-0.042^{\star * *}$ & $-0.035^{\star \star}$ & $-0.041^{* * *}$ & $-0.036^{\star \star}$ & $-0.029^{*}$ & $-0.035^{\star *}$ & $-0.036^{\star \star}$ & $-0.030^{\star}$ & $-0.035^{\star \star}$ & $-0.000^{* *}$ & $-0.000^{\star *}$ & $-0.000^{* *}$ \\
\hline & $(-2.80)$ & $(-2.34)$ & $(-2.72)$ & $(-2.39)$ & $(-1.90)$ & $(-2.26)$ & $(-2.44)$ & $(-1.95)$ & $(-2.30)$ & $(-2.48)$ & $(-2.09)$ & $(-2.48)$ \\
\hline \multirow[t]{2}{*}{$\operatorname{SIZE}_{t-1}$} & $-0.454^{* * *}$ & $-0.427^{\star * *}$ & $-0.487^{* * *}$ & $-0.325^{\star *}$ & -0.283 & $-0.340^{*}$ & $-0.331^{* *}$ & -0.288 & $-0.345^{\star}$ & 0.000 & 0.000 & 0.000 \\
\hline & $(-2.95)$ & $(-2.65)$ & $(-2.99)$ & $(-1.97)$ & $(-1.60)$ & $(-1.90)$ & $(-2.01)$ & $(-1.64)$ & $(-1.94)$ & (1.01) & $(1.10)$ & $(0.76)$ \\
\hline \multirow[t]{2}{*}{ GROWTH $_{\mathrm{t}-1}$} & 0.557 & 0.622 & 0.631 & 0.505 & 0.567 & 0.576 & 0.532 & 0.595 & 0.604 & 0.001 & 0.001 & 0.001 \\
\hline & $(0.41)$ & $(0.43)$ & $(0.44)$ & $(0.40)$ & $(0.42)$ & $(0.43)$ & $(0.42)$ & $(0.44)$ & $(0.45)$ & $(0.50)$ & $(0.50)$ & $(0.51)$ \\
\hline \multirow[t]{2}{*}{ LEVERAGE $_{\mathrm{t}-1}$} & 1.455 & 1.474 & 1.903 & 0.933 & 0.818 & 1.230 & 0.959 & 0.847 & 1.258 & 0.001 & 0.000 & 0.001 \\
\hline & $(1.24)$ & $(1.21)$ & $(1.55)$ & $(0.81)$ & $(0.67)$ & $(1.00)$ & $(0.83)$ & $(0.70)$ & $(1.03)$ & $(0.41)$ & $(0.37)$ & $(0.73)$ \\
\hline \multirow[t]{2}{*}{ CASHFLOW ${ }_{t-1}$} & $-0.064^{* * *}$ & $-0.065^{\star * *}$ & $-0.062^{* * *}$ & $-0.069^{* * *}$ & $-0.071^{* * *}$ & $-0.067^{* * *}$ & $-0.069^{* * *}$ & $-0.071^{* * *}$ & $-0.068^{* * *}$ & $-0.000^{* * *}$ & $-0.000^{* * *}$ & $-0.000^{* * *}$ \\
\hline & $(-3.86)$ & $(-3.88)$ & $(-3.83)$ & $(-3.45)$ & $(-3.49)$ & $(-3.40)$ & $(-3.47)$ & $(-3.51)$ & $(-3.42)$ & $(-3.28)$ & $(-3.28)$ & $(-3.15)$ \\
\hline \multirow[t]{2}{*}{ CAPITAL $_{\mathrm{t}-1}$} & $9.823^{* *}$ & $8.963^{*}$ & 7.954 & $11.572^{\star *}$ & $10.615^{\star *}$ & $9.645^{*}$ & $11.466^{* *}$ & $10.518^{* *}$ & $9.551^{*}$ & 0.008 & 0.007 & 0.006 \\
\hline & $(2.02)$ & $(1.79)$ & $(1.61)$ & $(2.37)$ & $(2.12)$ & (1.95) & $(2.36)$ & $(2.11)$ & $(1.93)$ & $(1.43)$ & $(1.25)$ & $(1.06)$ \\
\hline \multirow[t]{2}{*}{$R \& D_{t-1}$} & $-0.105^{\star \star \star}$ & $-0.097^{\star \star *}$ & $-0.098^{\star * *}$ & $-0.101^{* \star *}$ & $-0.096^{\star \star *}$ & $-0.097^{\star * *}$ & $-0.101^{\star \star \star}$ & $-0.095^{\star \star *}$ & $-0.097^{\star \star \star}$ & $-0.000^{\star \star *}$ & $-0.000^{* * *}$ & $-0.000^{\star * *}$ \\
\hline & $(-3.21)$ & $(-2.86)$ & $(-2.95)$ & $(-3.44)$ & $(-3.14)$ & $(-3.25)$ & $(-3.46)$ & $(-3.16)$ & $(-3.27)$ & $(-4.26)$ & $(-3.96)$ & $(-4.07)$ \\
\hline \multirow[t]{2}{*}{ Constant } & $30.484^{\star * *}$ & $29.729^{\star \star \star}$ & $32.105^{\star \star *}$ & $27.814^{* * *}$ & $27.003^{\star \star *}$ & $29.287^{\star \star \star}$ & $27.848^{\star \star *}$ & $27.029^{\star \star \star}$ & $29.305^{\star \star *}$ & $0.026^{\star \star *}$ & $0.025^{\star \star *}$ & $0.028^{* * *}$ \\
\hline & $(11.04)$ & (10.61) & $(11.27)$ & $(9.81)$ & $(9.36)$ & $(9.91)$ & $(9.84)$ & $(9.39)$ & $(9.94)$ & $(8.26)$ & $(7.88)$ & $(8.52)$ \\
\hline Industry Effects & YES & YES & YES & YES & YES & YES & YES & YES & YES & YES & YES & YES \\
\hline Year Effects & YES & YES & YES & YES & YES & YES & YES & YES & YES & YES & YES & YES \\
\hline Observations & 1351 & 1305 & 1305 & 1351 & 1305 & 1305 & 1351 & 1305 & 1305 & 1351 & 1305 & 1305 \\
\hline Adj. R-squared & 0.433 & 0.420 & 0.428 & 0.388 & 0.376 & 0.384 & 0.388 & 0.376 & 0.384 & 0.492 & 0.481 & 0.488 \\
\hline $\mathrm{F}$ & 30.385 & 28.248 & 28.222 & 31.003 & 28.667 & 28.877 & 31.117 & 28.789 & 29.003 & 41.912 & 38.588 & 38.486 \\
\hline
\end{tabular}


Note: Dependent variables - CAPM_IDIO (Models (1)-(3)), FAMA_IDIO (Models (4)-(6)), CARHART_IDIO (Models (7)-(9)), and DEVRET (Models (10)-(12)), respectively. EE is defined in Table 2 and is constructed in a way that the higher firms' sales/emissions generate higher score for environmental performance. Year and industry dummies are included to control for year industry fixed effects. The numbers in parentheses are the heteroskedasticity-robust standard errors. The definitions of variables are presented in Table $2 .{ }^{*},{ }^{* *}$ and ${ }^{* * *}$ indicate significance levels at $0.10,0.05$ and 0.01 (2-tail), respectively. 
Table 6 Environmental management performance and firm risk-2SLS

\begin{tabular}{|c|c|c|c|c|}
\hline & CAPM_IDIO & FAMA_IDIO & CARHART_IDIO & TOTOL RISK \\
\hline & (1) & (2) & (3) & (4) \\
\hline \multirow[t]{2}{*}{ EMP_Hat $t_{-1}$} & $-1.033^{* * *}$ & $-1.062^{* * *}$ & $-1.056^{* * *}$ & $-1.173^{* * *}$ \\
\hline & $(-2.84)$ & $(-2.61)$ & $(-2.61)$ & $(-2.72)$ \\
\hline \multirow[t]{2}{*}{$\operatorname{ROS}_{t-1}$} & -0.004 & -0.004 & -0.004 & -0.004 \\
\hline & $(-0.76)$ & $(-0.67)$ & $(-0.66)$ & $(-0.62)$ \\
\hline \multirow[t]{2}{*}{$\mathrm{UNGC}_{\mathrm{t}-1}$} & 1.719 & 1.934 & 1.935 & 2.021 \\
\hline & $(1.30)$ & $(1.42)$ & $(1.43)$ & $(1.36)$ \\
\hline \multirow[t]{2}{*}{ CGSCORE $_{\mathrm{t}-1}$} & $0.140^{*}$ & $0.147^{*}$ & $0.145^{*}$ & $0.168^{*}$ \\
\hline & $(1.78)$ & $(1.66)$ & $(1.65)$ & $(1.81)$ \\
\hline \multirow[t]{2}{*}{$\operatorname{SIZE}_{\mathrm{t}-1}$} & $2.739^{* *}$ & $2.935^{\star \star}$ & $2.914^{\star *}$ & $3.844^{* *}$ \\
\hline & $(2.10)$ & $(2.01)$ & $(2.00)$ & $(2.48)$ \\
\hline \multirow[t]{2}{*}{ GROWTH $_{\mathrm{t}-1}$} & $-8.784^{\star *}$ & $-8.933^{\star *}$ & $-8.971^{* *}$ & $-9.602^{\star *}$ \\
\hline & $(-2.33)$ & $(-2.20)$ & $(-2.22)$ & $(-2.23)$ \\
\hline \multirow[t]{2}{*}{ LEVERAGE $_{\mathrm{t}-1}$} & $5.230^{* *}$ & $4.826^{\star *}$ & $4.822^{* *}$ & 3.947 \\
\hline & $(2.18)$ & $(2.00)$ & $(2.01)$ & $(1.50)$ \\
\hline \multirow[t]{2}{*}{ CASHFLOW ${ }_{\mathrm{t}-1}$} & $-0.111^{\star \star \star}$ & $-0.109^{\star \star *}$ & $-0.109^{* * *}$ & $-0.116^{* \star *}$ \\
\hline & $(-3.22)$ & $(-3.01)$ & $(-3.02)$ & $(-3.09)$ \\
\hline \multirow[t]{2}{*}{ CAPITAL ${ }_{t-1}$} & $44.218^{* *}$ & $45.192^{* *}$ & $44.900^{* *}$ & $48.000^{\star *}$ \\
\hline & $(2.42)$ & $(2.28)$ & $(2.28)$ & $(2.26)$ \\
\hline \multirow{2}{*}{$R \& D_{t-1}$} & -0.048 & -0.045 & -0.045 & -0.096 \\
\hline & $(-0.83)$ & $(-0.80)$ & $(-0.80)$ & $(-1.51)$ \\
\hline \multirow[t]{2}{*}{ Constant } & $26.420^{*}$ & 22.154 & 22.218 & 17.300 \\
\hline & $(1.91)$ & $(1.53)$ & $(1.54)$ & $(1.21)$ \\
\hline Industry-fixed Effects & YES & YES & YES & YES \\
\hline Year-fixed Effects & YES & YES & YES & YES \\
\hline Observations & 1105 & 1105 & 1105 & 1105 \\
\hline \multicolumn{5}{|c|}{ Hausman Test of Endogeneity } \\
\hline$x^{2}$ & 69.42 & 65.81 & 66.21 & 54.67 \\
\hline$p$-value & 0.00 & 0.00 & 0.00 & 0.00 \\
\hline \multicolumn{5}{|l|}{ Over-identification Test } \\
\hline$x^{2}$ & 0.67 & 1.14 & 1.15 & 1.71 \\
\hline$p$-value & 0.72 & 0.57 & 0.56 & 0.42 \\
\hline \multicolumn{5}{|c|}{ Test of Weak Instruments } \\
\hline F-statistic & 5.17 & 5.17 & 5.17 & 5.17 \\
\hline$p$-value & 0.00 & 0.00 & 0.00 & 0.00 \\
\hline Partial R-squared & 0.01 & 0.01 & 0.01 & 0.01 \\
\hline
\end{tabular}

Note: This table presents the results of our second-stage results. The numbers in parentheses are the heteroskedasticity-robust standard errors. ${ }^{*},{ }^{* *}$ and ${ }^{* * *}$ indicate significance levels at $0.10,0.05$ and 0.01 (2-tail), respectively. The definitions of variables are presented in Table 2, and EMP_Hat represents the instrumented EMP value. 
Table 7 Relationship between multi-dimensional environmental performance and firm risk (Manufacturing industries)

\begin{tabular}{|c|c|c|c|c|c|c|c|c|c|c|c|c|}
\hline & $\begin{array}{c}\text { CAPM_IDIO } \\
(\mathrm{t})\end{array}$ & $\begin{array}{c}\text { CAPM_IDIO } \\
(\mathrm{t})\end{array}$ & $\begin{array}{c}\text { CAPM_IDIO } \\
(\mathrm{t})\end{array}$ & $\begin{array}{c}\text { FAMA_IDIO } \\
(\mathrm{t})\end{array}$ & $\begin{array}{c}\text { FAMA_IDIO } \\
(\mathrm{t})\end{array}$ & $\begin{array}{c}\text { FAMA_IDIO } \\
(\mathrm{t})\end{array}$ & $\begin{array}{c}\text { CARHART_IDIO } \\
(\mathrm{t})\end{array}$ & $\begin{array}{c}\text { CARHART_IDIO } \\
(\mathrm{t})\end{array}$ & $\begin{array}{c}\text { CARHART_IDIO } \\
(\mathrm{t})\end{array}$ & $\begin{array}{c}\text { DEVRET } \\
(\mathrm{t})\end{array}$ & $\begin{array}{c}\text { DEVRET } \\
(\mathrm{t})\end{array}$ & $\begin{array}{c}\text { DEVRET } \\
(\mathrm{t})\end{array}$ \\
\hline & (1) & (2) & (3) & (4) & (5) & (6) & (7) & (8) & (9) & (10) & (11) & (12) \\
\hline \multirow[t]{2}{*}{$\mathrm{EMP}_{\mathrm{t}-1}$} & $-0.055^{\star *}$ & -0.044 & $-0.063^{* *}$ & $-0.073^{* * *}$ & $-0.066^{\star *}$ & $-0.084^{* * *}$ & $-0.071^{* * *}$ & $-0.064^{* *}$ & $-0.082^{* * *}$ & $-0.000^{\star * *}$ & $-0.000^{* * *}$ & $-0.000^{* * *}$ \\
\hline & $(-1.97)$ & $(-1.46)$ & $(-2.00)$ & $(-2.70)$ & $(-2.28)$ & $(-2.74)$ & $(-2.67)$ & $(-2.24)$ & $(-2.71)$ & $(-3.89)$ & $(-3.26)$ & $(-3.25)$ \\
\hline \multirow[t]{2}{*}{$\mathrm{EE}_{\mathrm{t}-1}$} & & 0.585 & -3.182 & & 0.273 & -3.175 & & 0.284 & -3.143 & & $0.001^{*}$ & $-0.005^{\star *}$ \\
\hline & & $(0.94)$ & $(-1.31)$ & & $(0.53)$ & $(-1.61)$ & & $(0.56)$ & $(-1.60)$ & & $(1.72)$ & $(-2.05)$ \\
\hline \multirow[t]{2}{*}{$E E_{t-1} * E M_{t-1}$} & & & 0.074 & & & 0.068 & & & 0.067 & & & $0.000^{* *}$ \\
\hline & & & $(1.37)$ & & & $(1.58)$ & & & $(1.57)$ & & & $(2.29)$ \\
\hline \multirow[t]{2}{*}{$\operatorname{ROS}_{t-1}$} & -0.010 & -0.009 & -0.008 & -0.008 & -0.007 & -0.006 & -0.009 & -0.008 & -0.007 & -0.000 & -0.000 & -0.000 \\
\hline & $(-0.59)$ & $(-0.51)$ & $(-0.48)$ & $(-0.49)$ & $(-0.41)$ & $(-0.39)$ & $(-0.55)$ & $(-0.48)$ & $(-0.45)$ & $(-0.32)$ & $(-0.24)$ & $(-0.20)$ \\
\hline \multirow[t]{2}{*}{$U_{N G C}{ }_{t-1}$} & $-1.142^{\star *}$ & $-1.099^{* *}$ & $-0.948^{\star *}$ & $-1.109^{\star *}$ & $-1.078^{\star *}$ & $-0.939^{* *}$ & $-1.115^{\star *}$ & $-1.087^{\star *}$ & $-0.949^{\star *}$ & $-0.001^{* *}$ & $-0.001^{*}$ & -0.001 \\
\hline & $(-2.44)$ & $(-2.37)$ & $(-2.00)$ & $(-2.47)$ & $(-2.41)$ & $(-2.07)$ & $(-2.51)$ & $(-2.45)$ & $(-2.10)$ & $(-2.15)$ & $(-1.94)$ & $(-1.47)$ \\
\hline \multirow[t]{2}{*}{$\operatorname{CGSCORE}_{\mathrm{t}-1}$} & $-0.032^{*}$ & -0.019 & -0.020 & -0.021 & -0.009 & -0.010 & -0.022 & -0.009 & -0.010 & -0.000 & -0.000 & -0.000 \\
\hline & $(-1.67)$ & $(-1.07)$ & $(-1.12)$ & $(-1.23)$ & $(-0.52)$ & $(-0.57)$ & $(-1.27)$ & $(-0.56)$ & $(-0.61)$ & $(-1.57)$ & $(-1.16)$ & $(-1.25)$ \\
\hline \multirow[t]{2}{*}{$\operatorname{SIZE}_{t-1}$} & $-1.019^{* * *}$ & $-1.037^{\star * *}$ & $-0.995^{\star * *}$ & $-0.940^{* * *}$ & $-0.959^{* * *}$ & $-0.921^{* * *}$ & $-0.947^{* * *}$ & $-0.966^{* * *}$ & $-0.928^{* * *}$ & $-0.000^{* *}$ & $-0.000^{* *}$ & $-0.000^{*}$ \\
\hline & $(-5.39)$ & $(-5.37)$ & $(-5.04)$ & $(-5.05)$ & $(-5.03)$ & $(-4.75)$ & $(-5.13)$ & $(-5.11)$ & $(-4.82)$ & $(-2.14)$ & $(-2.18)$ & $(-1.86)$ \\
\hline \multirow[t]{2}{*}{ GROWTH $_{\mathrm{t}-1}$} & 0.778 & 0.901 & 0.905 & 0.254 & 0.404 & 0.407 & 0.285 & 0.433 & 0.437 & 0.001 & 0.001 & 0.001 \\
\hline & $(0.38)$ & $(0.41)$ & $(0.41)$ & $(0.13)$ & $(0.20)$ & $(0.20)$ & $(0.15)$ & $(0.21)$ & $(0.21)$ & $(0.44)$ & $(0.44)$ & $(0.44)$ \\
\hline \multirow[t]{2}{*}{ LEVERAGE $_{\mathrm{t}-1}$} & 1.540 & 2.574 & $2.784^{*}$ & 1.279 & 2.044 & 2.236 & 1.325 & 2.103 & 2.294 & 0.000 & 0.002 & 0.002 \\
\hline & $(0.91)$ & $(1.53)$ & $(1.65)$ & $(0.80)$ & $(1.28)$ & $(1.40)$ & $(0.83)$ & $(1.33)$ & $(1.45)$ & $(0.28)$ & $(0.90)$ & $(1.09)$ \\
\hline \multirow[t]{2}{*}{ CASHFLOW $_{\mathrm{t}-1}$} & -0.036 & -0.031 & -0.034 & -0.035 & -0.033 & -0.035 & -0.035 & -0.033 & -0.035 & -0.000 & -0.000 & -0.000 \\
\hline & $(-1.60)$ & $(-1.35)$ & $(-1.50)$ & $(-1.61)$ & $(-1.47)$ & $(-1.60)$ & $(-1.63)$ & $(-1.48)$ & $(-1.62)$ & $(-1.26)$ & $(-0.97)$ & $(-1.17)$ \\
\hline \multirow[t]{2}{*}{ CAPITAL $_{\mathrm{t}-1}$} & $18.013^{* *}$ & $18.568^{* *}$ & $18.879^{* *}$ & $20.953^{* \star *}$ & $20.920^{\star * *}$ & $21.206^{\star \star *}$ & $20.891^{* * *}$ & $20.901^{* * *}$ & $21.184^{* * *}$ & $0.016^{\star *}$ & $0.018^{\star *}$ & $0.018^{* *}$ \\
\hline & $(2.46)$ & $(2.47)$ & $(2.50)$ & $(2.90)$ & $(2.80)$ & $(2.83)$ & $(2.90)$ & $(2.81)$ & $(2.83)$ & $(2.02)$ & $(2.15)$ & $(2.21)$ \\
\hline \multirow[t]{2}{*}{$R \& D_{t-1}$} & $-0.079^{* *}$ & $-0.060^{*}$ & $-0.059^{*}$ & $-0.073^{* * *}$ & $-0.060^{* *}$ & $-0.060^{* *}$ & $-0.073^{* * *}$ & $-0.060^{* *}$ & $-0.060^{\star *}$ & $-0.000^{* * *}$ & $-0.000^{* * *}$ & $-0.000^{* * *}$ \\
\hline & $(-2.51)$ & $(-1.87)$ & $(-1.87)$ & $(-2.61)$ & $(-2.09)$ & $(-2.09)$ & $(-2.64)$ & $(-2.10)$ & $(-2.11)$ & $(-3.89)$ & $(-3.26)$ & $(-3.25)$ \\
\hline \multirow[t]{2}{*}{ Constant } & $38.033^{* * *}$ & $36.363^{* * *}$ & $36.783^{* \star *}$ & $36.072^{\star \star *}$ & $34.883^{* * *}$ & $35.267^{* \star *}$ & $36.128^{\star * *}$ & $34.912^{\star * *}$ & $35.294^{* * *}$ & $0.034^{* * *}$ & $0.032^{* * *}$ & $0.033^{* * *}$ \\
\hline & $(11.87)$ & $(10.93)$ & $(11.22)$ & $(11.81)$ & (10.98) & $(11.23)$ & $(11.89)$ & $(11.05)$ & $(11.30)$ & $(9.87)$ & (8.98) & $(9.30)$ \\
\hline Industry Effects & YES & YES & YES & YES & YES & YES & YES & YES & YES & YES & YES & YES \\
\hline Year Effects & YES & YES & YES & YES & YES & YES & YES & YES & YES & YES & YES & YES \\
\hline Observations & 776 & 752 & 752 & 776 & 752 & 752 & 776 & 752 & 752 & 776 & 752 & 752 \\
\hline Adj. R-squared & 0.462 & 0.441 & 0.442 & 0.461 & 0.440 & 0.441 & 0.460 & 0.440 & 0.441 & 0.541 & 0.525 & 0.528 \\
\hline $\mathrm{F}$ & 20.546 & 19.252 & 18.616 & 22.353 & 20.869 & 20.187 & 22.528 & 21.091 & 20.398 & 30.643 & 28.138 & 27.460 \\
\hline
\end{tabular}


Note: Dependent variables - CAPM_IDIO (Models (1)-(3)), FAMA_IDIO (Models (4)-(6)), CARHART_IDIO (Models (7)-(9)), and DEVRET (Models (10)-(12)), respectively. EE is defined in Table 2 and is constructed in a way that the higher firms' sales/emissions generate higher score for environmental performance. Year and industry dummies are included to control for year industry fixed effects. The numbers in parentheses are the heteroskedasticity-robust standard errors. The definitions of variables are presented in Table $2 .{ }^{*},{ }^{* *}$ and ${ }^{* * *}$ indicate significance levels at $0.10,0.05$ and 0.01 (2-tail), respectively. 
Table 8 Relationship between multi-dimensional environmental performance and firm risk (Service industries)

\begin{tabular}{|c|c|c|c|c|c|c|c|c|c|c|c|c|}
\hline & $\begin{array}{c}\text { CAPM_IDIO } \\
(\mathrm{t})\end{array}$ & $\begin{array}{c}\text { CAPM_IDIO } \\
(\mathrm{t})\end{array}$ & $\begin{array}{c}\text { CAPM_IDIO } \\
(\mathrm{t})\end{array}$ & $\begin{array}{c}\text { FAMA_IDIO } \\
(\mathrm{t})\end{array}$ & $\begin{array}{c}\text { FAMA_IDIO } \\
(\mathrm{t})\end{array}$ & $\begin{array}{c}\text { FAMA_IDIO } \\
(\mathrm{t})\end{array}$ & $\begin{array}{c}\text { CARHART_IDIO } \\
(\mathrm{t})\end{array}$ & $\begin{array}{c}\text { CARHART_IDIO } \\
(\mathrm{t})\end{array}$ & $\begin{array}{c}\text { CARHART_IDIO } \\
(\mathrm{t})\end{array}$ & $\begin{array}{c}\text { DEVRET } \\
(\mathrm{t})\end{array}$ & $\begin{array}{c}\text { DEVRET } \\
(\mathrm{t})\end{array}$ & $\begin{array}{c}\text { DEVRET } \\
(\mathrm{t})\end{array}$ \\
\hline & (1) & (2) & (3) & (4) & (5) & (6) & (7) & (8) & (9) & (10) & (11) & (12) \\
\hline \multirow[t]{2}{*}{$\mathrm{EMP}_{\mathrm{t}-1}$} & -0.039 & -0.052 & $-0.077^{\star *}$ & -0.029 & -0.044 & $-0.066^{*}$ & -0.028 & -0.043 & $-0.066^{*}$ & -0.000 & -0.000 & $-0.000^{* *}$ \\
\hline & $(-1.25)$ & $(-1.64)$ & $(-2.37)$ & $(-0.88)$ & $(-1.28)$ & $(-1.91)$ & $(-0.86)$ & $(-1.26)$ & $(-1.89)$ & $(-1.23)$ & $(-1.56)$ & $(-2.22)$ \\
\hline \multirow[t]{2}{*}{$E E_{t-1}$} & & -0.168 & $-1.772^{* * *}$ & & -0.196 & $-1.614^{* * *}$ & & -0.197 & $-1.610^{* * *}$ & & -0.000 & $-0.002^{* * *}$ \\
\hline & & $(-1.24)$ & $(-3.27)$ & & $(-1.43)$ & $(-2.97)$ & & $(-1.44)$ & $(-2.96)$ & & $(-1.11)$ & $(-3.19)$ \\
\hline \multirow[t]{2}{*}{$\mathrm{EE}_{\mathrm{t}-1} * \mathrm{EMP}_{\mathrm{t}-1}$} & & & $0.032^{* * *}$ & & & $0.028^{* * *}$ & & & $0.028^{* * *}$ & & & $0.000^{* * *}$ \\
\hline & & & (2.99) & & & $(2.65)$ & & & (2.65) & & & $(2.86)$ \\
\hline \multirow[t]{2}{*}{$\operatorname{ROS}_{t-1}$} & $-0.006^{*}$ & $-0.005^{*}$ & $-0.005^{*}$ & $-0.005^{*}$ & -0.004 & -0.004 & $-0.005^{*}$ & -0.005 & -0.004 & $-0.000^{*}$ & -0.000 & -0.000 \\
\hline & $(-1.81)$ & $(-1.69)$ & $(-1.66)$ & $(-1.65)$ & $(-1.50)$ & $(-1.45)$ & $(-1.70)$ & $(-1.55)$ & $(-1.51)$ & $(-1.74)$ & $(-1.59)$ & $(-1.51)$ \\
\hline \multirow[t]{2}{*}{$U N G C_{t-1}$} & -0.147 & -0.069 & 0.028 & 0.088 & 0.176 & 0.262 & 0.098 & 0.186 & 0.271 & 0.000 & 0.000 & 0.000 \\
\hline & $(-0.16)$ & $(-0.07)$ & $(0.03)$ & $(0.09)$ & $(0.17)$ & $(0.25)$ & $(0.10)$ & $(0.18)$ & $(0.26)$ & $(0.17)$ & $(0.24)$ & $(0.32)$ \\
\hline \multirow[t]{2}{*}{$\operatorname{CGSCORE}_{\mathrm{t}-1}$} & $-0.065^{\star * *}$ & $-0.064^{* * *}$ & $-0.071^{* * *}$ & $-0.066^{* *}$ & $-0.065^{\star *}$ & $-0.071^{* * *}$ & $-0.067^{* * *}$ & $-0.066^{\star *}$ & $-0.072^{* * *}$ & $-0.000^{\star *}$ & $-0.000^{\star *}$ & $-0.000^{* *}$ \\
\hline & $(-2.76)$ & $(-2.59)$ & $(-2.84)$ & $(-2.57)$ & $(-2.40)$ & $(-2.60)$ & $(-2.60)$ & $(-2.42)$ & $(-2.62)$ & $(-2.56)$ & $(-2.35)$ & $(-2.58)$ \\
\hline \multirow[t]{2}{*}{$\operatorname{SIZE}_{\mathrm{t}-1}$} & -0.235 & -0.176 & -0.243 & -0.141 & -0.065 & -0.124 & -0.147 & -0.070 & -0.130 & $0.000^{*}$ & $0.000^{*}$ & 0.000 \\
\hline & $(-1.15)$ & $(-0.82)$ & $(-1.11)$ & $(-0.65)$ & $(-0.28)$ & $(-0.52)$ & $(-0.67)$ & $(-0.30)$ & $(-0.54)$ & $(1.70)$ & $(1.90)$ & $(1.58)$ \\
\hline \multirow[t]{2}{*}{ GROWTH $_{t-1}$} & 1.129 & 1.133 & 1.120 & 1.738 & 1.731 & 1.719 & 1.767 & 1.760 & 1.749 & 0.002 & 0.001 & 0.001 \\
\hline & $(0.71)$ & $(0.69)$ & $(0.69)$ & (1.13) & $(1.10)$ & (1.09) & $(1.16)$ & $(1.12)$ & (1.11) & $(0.89)$ & $(0.81)$ & $(0.81)$ \\
\hline \multirow[t]{2}{*}{ LEVERAGE $_{\mathrm{t}-1}$} & $3.516^{* *}$ & $3.036^{*}$ & $3.298^{*}$ & $3.090^{*}$ & 2.540 & 2.771 & $3.107^{*}$ & 2.556 & 2.787 & $0.003^{*}$ & 0.002 & 0.003 \\
\hline & $(2.10)$ & (1.74) & (1.87) & $(1.82)$ & $(1.42)$ & $(1.54)$ & $(1.84)$ & $(1.44)$ & (1.55) & $(1.66)$ & $(1.30)$ & $(1.44)$ \\
\hline \multirow[t]{2}{*}{ CASHFLOW $_{t-1}$} & $-0.076^{\star \star \star}$ & $-0.081^{* \star *}$ & $-0.076^{* \star \star}$ & $-0.087^{\star \star \star}$ & $-0.092^{\star \star *}$ & $-0.089^{\star \star \star}$ & $-0.087^{\star \star \star}$ & $-0.093^{\star \star *}$ & $-0.089^{\star * *}$ & $-0.000^{\star * *}$ & $-0.000^{\star * *}$ & $-0.000^{* * *}$ \\
\hline & $(-3.50)$ & $(-3.68)$ & $(-3.63)$ & $(-3.30)$ & $(-3.44)$ & $(-3.33)$ & $(-3.30)$ & $(-3.45)$ & $(-3.34)$ & $(-3.21)$ & $(-3.32)$ & $(-3.20)$ \\
\hline \multirow[t]{2}{*}{ CAPITAL $_{t-1}$} & -11.010 & -12.425 & $-12.887^{*}$ & $-13.244^{*}$ & $-14.855^{\star}$ & $-15.264^{* *}$ & $-13.404^{*}$ & $-15.034^{*}$ & $-15.441^{* *}$ & $-0.017^{* *}$ & $-0.018^{* *}$ & $-0.018^{* *}$ \\
\hline & $(-1.44)$ & $(-1.57)$ & $(-1.66)$ & $(-1.76)$ & $(-1.91)$ & $(-1.99)$ & $(-1.78)$ & $(-1.93)$ & $(-2.01)$ & $(-2.04)$ & $(-2.11)$ & $(-2.21)$ \\
\hline \multirow[t]{2}{*}{$R \& D_{t-1}$} & -0.142 & -0.137 & -0.168 & -0.121 & -0.075 & -0.103 & -0.108 & -0.062 & -0.089 & -0.000 & -0.000 & -0.000 \\
\hline & $(-0.28)$ & $(-0.25)$ & $(-0.28)$ & $(-0.22)$ & $(-0.12)$ & $(-0.16)$ & $(-0.20)$ & $(-0.10)$ & $(-0.14)$ & $(-0.43)$ & $(-0.29)$ & $(-0.32)$ \\
\hline \multirow[t]{2}{*}{ Constant } & $26.363^{\star \star \star}$ & $25.826^{\star \star *}$ & $28.594^{\star \star *}$ & $24.062^{\star \star \star}$ & $23.410^{\star \star \star}$ & $25.857^{\star \star \star}$ & $24.134^{\star \star *}$ & $23.477^{\star * \star}$ & $25.916^{\star \star \star}$ & $0.021^{* * *}$ & $0.020^{\star * \star}$ & $0.023^{\star * *}$ \\
\hline & $(7.28)$ & $(7.08)$ & $(7.45)$ & $(6.48)$ & $(6.26)$ & $(6.48)$ & $(6.50)$ & $(6.29)$ & $(6.51)$ & $(5.10)$ & $(4.88)$ & $(5.21)$ \\
\hline Industry Effects & YES & YES & YES & YES & YES & YES & YES & YES & YES & YES & YES & YES \\
\hline Year Effects & YES & YES & YES & YES & YES & YES & YES & YES & YES & YES & YES & YES \\
\hline Observations & 575 & 553 & 553 & 575 & 553 & 553 & 575 & 553 & 553 & 575 & 553 & 553 \\
\hline Adj. R-squared & 0.450 & 0.449 & 0.458 & 0.378 & 0.379 & 0.385 & 0.380 & 0.380 & 0.386 & 0.488 & 0.486 & 0.492 \\
\hline $\mathrm{F}$ & 20.676 & 19.359 & 19.609 & 19.443 & 18.132 & 18.561 & 19.405 & 18.093 & 18.527 & 26.058 & 23.525 & 23.636 \\
\hline
\end{tabular}


Note: Dependent variables - CAPM_IDIO (Models (1)-(3)), FAMA_IDIO (Models (4)-(6)), CARHART_IDIO (Models (7)-(9)), and DEVRET (Models (10)-(12)), respectively. EE is defined in Table 2 and is constructed in a way that the higher firms' sales/emissions generate higher score for environmental performance. Year and industry dummies are included to control for year industry fixed effects. The numbers in parentheses are the heteroskedasticity-robust standard errors. The definitions of variables are presented in Table $2 .{ }^{*},{ }^{* *}$ and ${ }^{* * *}$ indicate significance levels at $0.10,0.05$ and 0.01 (2-tail), respectively. 
Appendix 1 CEP indicators as derived from the ASSET4 database

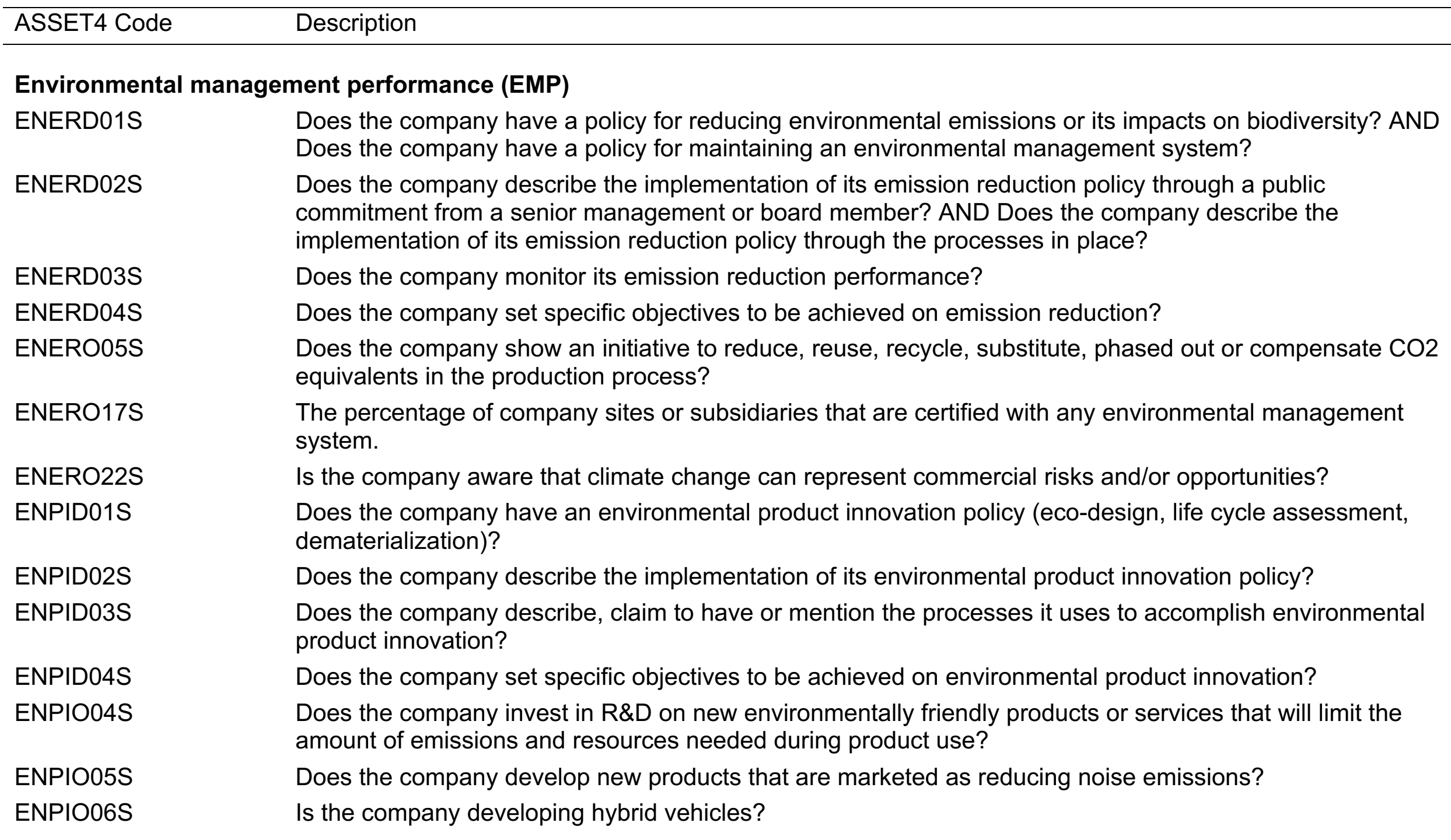



wind, solar, hydro and geo-thermal and biomass power)?
ENPIO10S
ENPIO12S
ENPIO17S
ENPIO18S
ENPIO20S
ENRRD01S
ENRRD02S
ENRRD03S
ENRRD04S
ENRRO07S
ENRRO11S
Is the company a signatory of the Equator Principles (commitment to manage environmental issues in project financing)? OR Does the company claim to evaluate projects on the basis of environmental or biodiversity risks as well?
Does the company develop new products and services linked to liquefied natural gas?
Does the company make a commitment to exclude GMO ingredients from its products or retail offerings?
Does the company develop products and services that improve the energy efficiency of buildings?
Has the company received product awards with respect to environmental responsibility? OR Does the company use product labels (e.g., FSC, Energy Star, MSC) indicating the environmental responsibility of its products?
Does the company have a policy for reducing the use of natural resources? AND Does the company have a policy to lessen the environmental impact of its supply chain?
Does the company describe the implementation of its resource efficiency policy through a public commitment from a senior management or board member? AND Does the company describe the implementation of its resource efficiency policy through the processes in place?
Does the company monitor its resource efficiency performance?
Does the company set specific objectives to be achieved on resource efficiency? AND Does the company comment on the results of previously set objectives?
Does the company have environmentally friendly or green sites or offices?
Does the company use environmental criteria (ISO 14000, energy consumption, etc.) in the selection process of its suppliers or sourcing partners? AND Does the company report or show to be ready to end a partnership with a sourcing partner, if environmental criteria are not met?

ENERO01S

Does the company report on initiatives to protect, restore or reduce its impact on native ecosystems and 
species, biodiversity, protected and sensitive areas?

ENERO06S

ENERO07S

ENERO08S

ENERO09S

ENER014S

ENERO15S

ENERO16S

ENERO18S

ENERO19S

ENERO21S

ENERO24S

ENPIO01S

ENPIO02S
Does the company report on initiatives to recycle, reduce, reuse or phase out fluorinated gases such as HFCs (hydrofluorocarbons), PFCs (perfluorocarbons) or SF6 (sulphur hexafluoride)?

Does the company report on initiatives to reduce, substitute, or phase out ozone-depleting (CFC-11 equivalents, chlorofluorocarbon) substances?

Does the company report on initiatives to reduce, reuse, recycle, substitute, or phase out SOx (sulphur oxides) or NOx (nitrogen oxides) emissions?

Does the company report on initiatives to reduce, substitute, or phase out volatile organic compounds (VOC) or particulate matter less than ten microns in diameter (PM10)?

Does the company report on initiatives to recycle, reduce, reuse, substitute, treat or phase out total waste, hazardous waste or wastewater?

Does the company report on the concentration of production locations in order to limit the environmental impact during the production process? OR Does the company report on its participation in any emissions trading initiative? OR Does the company report on new production techniques to improve the global environmental impact (all emissions) during the production process?

Does the company report on partnerships or initiatives with specialized NGOs, industry organizations, governmental or supragovernmental organizations that focus on improving environmental issues?

Does the company report or provide information on company-generated initiatives to restore the environment?

Does the company report on initiatives to reduce the environmental impact of transportation of its products or its staff?

Does the company report on initiatives to reduce, avoid or minimize the effects of spills or other polluting events (crisis management system)?

Does the company report on its environmental expenditures or does the company report to make proactive environmental investments to reduce future risks or increase future opportunities?

Does the company report on at least one product line or service that is designed to have positive effects on the environment or which is environmentally labelled and marketed?

Does the company describe initiatives in place to reduce the energy footprint of its products during their 
use?

\begin{tabular}{ll}
\hline ENPIO09S & $\begin{array}{l}\text { Does the company report on assets under management which employ environmental screening criteria or } \\
\text { environmental factors in the investment selection process? } \\
\text { ENPIO13S }\end{array}$ \\
Does the company report on specific products which are designed for reuse, recycling or the reduction of \\
environmental impacts? \\
Does the company report or show initiatives to produce or promote organic food or other products? \\
ENPIO16S & $\begin{array}{l}\text { Does the company report about take-back procedures and recycling programmes to reduce the potential } \\
\text { risks of products entering the environment? OR Does the company report about product features and } \\
\text { applications or services that will promote responsible, efficient, cost-effective and environmentally } \\
\text { preferable use? } \\
\text { Does the company report on initiatives to reduce, reuse, substitute or phase out toxic chemicals or } \\
\text { substances? }\end{array}$ \\
\hline ENRRO08S & $\begin{array}{l}\text { Does the company report on initiatives to use renewable energy sources? AND Does the company report } \\
\text { on initiatives to increase its energy efficiency overall? } \\
\text { Does the company report on initiatives to reuse or recycle water? OR Does the company report on } \\
\text { initiatives to reduce the amount of water used? } \\
\text { ENRRO12S }\end{array} \quad \begin{array}{l}\text { Does the company report on initiatives to reduce the environmental impact on land owned, leased or } \\
\text { managed for production activities or extractive use? }\end{array}$ \\
\hline
\end{tabular}

\section{Environmental operational performance (EOP)}

ENERO03V Total $\mathrm{CO}_{2}$ and $\mathrm{CO}_{2}$ equivalents emission in tonnes divided by net sales or revenue.


Appendix 2 Descriptive statistics (Manufacturing and Service sub-sectors)

Manufacturing industries

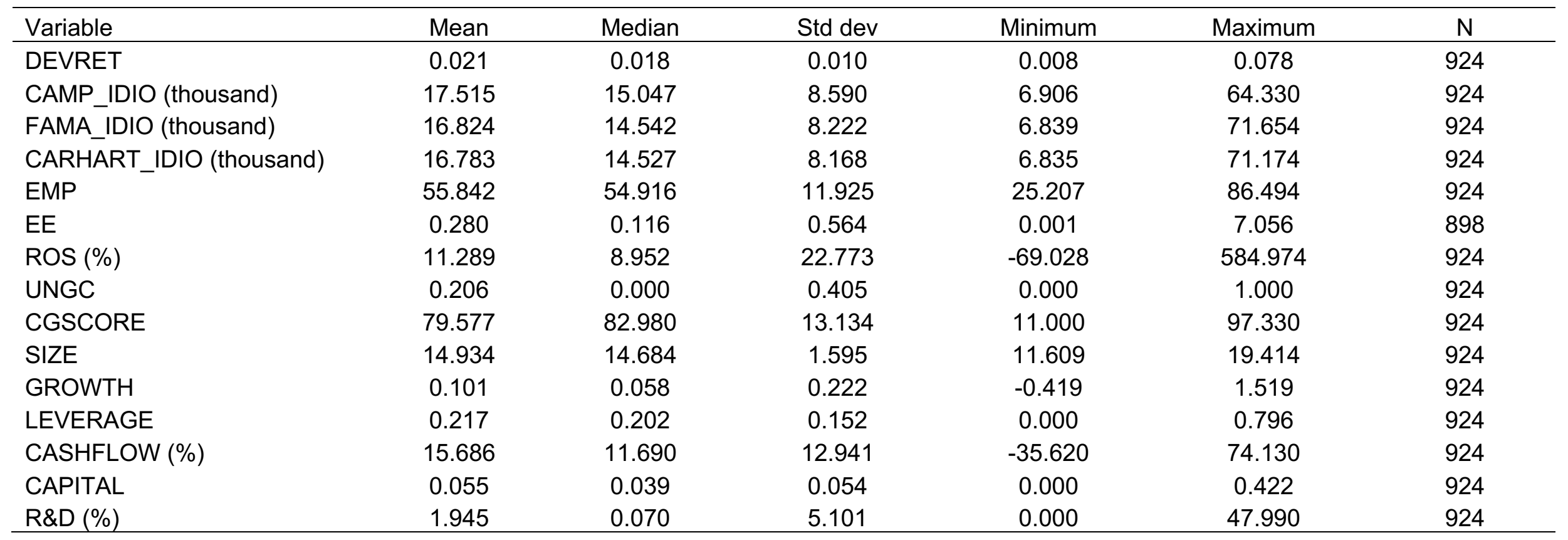


Service industries

\begin{tabular}{|c|c|c|c|c|c|c|}
\hline Variable & Mean & Median & Std dev & Minimum & Maximum & $\mathrm{N}$ \\
\hline DEVRET & 0.021 & 0.018 & 0.011 & 0.006 & 0.104 & 708 \\
\hline FAMA_IDIO (thousand) & 16.934 & 14.052 & 9.628 & 3.364 & 98.371 & 708 \\
\hline EMP & 54.215 & 53.640 & 11.775 & 23.952 & 83.129 & 708 \\
\hline EE & 1.266 & 0.324 & 2.823 & 0.001 & 20.239 & 684 \\
\hline ROS (\%) & 27.151 & 11.990 & 98.038 & -587.257 & 882.556 & 700 \\
\hline SIZE & 15.632 & 15.170 & 2.138 & 10.402 & 21.596 & 708 \\
\hline GROWTH & 0.071 & 0.041 & 0.217 & -0.419 & 1.519 & 708 \\
\hline LEVERAGE & 0.272 & 0.263 & 0.202 & 0.000 & 1.672 & 707 \\
\hline CASHFLOW (\%) & 17.916 & 15.345 & 18.298 & -44.500 & 78.660 & 708 \\
\hline CAPITAL & 0.037 & 0.021 & 0.044 & 0.000 & 0.330 & 708 \\
\hline
\end{tabular}

Note: This table reports univariate statistics (number of observations, mean, standard deviation, minimum and maximum). Manufacturing and service industries sub-samples consist of 924 and 708 firm-year observations respectively, covering all firms listed on the London Stock Exchange using the ASSET4 database over the 2002-2013 period. The definitions of variables are presented in Table 2. 